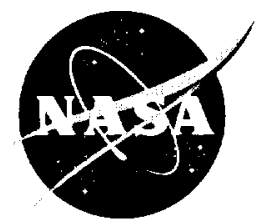

LWC and Temperature Effects on Ice Accretion Formation on Swept Wings at Glaze Ice Conditions

Mario Vargas

Glenn Research Center, Cleveland, Ohio

Eli Reshotko

Case Western Reserve University, Cleveland, Ohio 

Since its founding, NASA has been dedicated to the advancement of aeronautics and space science. The NASA Scientific and Technical Information (STI) Program Office plays a key part in helping NASA maintain this important role.

The NASA STI Program Office is operated by Langley Research Center, the Lead Center for NASA's scientific and technical information. The NASA STI Program Office provides access to the NASA STI Database, the largest collection of aeronautical and space science STI in the world. The Program Office is also NASA's institutional mechanism for disseminating the results of its research and development activities. These results are published by NASA in the NASA STI Report Series, which includes the following report types:

- TECHNICAL PUBLICATION. Reports of completed research or a major significant phase of research that present the results of NASA programs and include extensive data or theoretical analysis. Includes compilations of significant scientific and technical data and information deemed to be of continuing reference value. NASA's counterpart of peerreviewed formal professional papers but has less stringent limitations on manuscript length and extent of graphic presentations.

- TECHNICAL MEMORANDUM. Scientific and technical findings that are preliminary or of specialized interest, e.g., quick release reports, working papers, and bibliographies that contain minimal annotation. Does not contain extensive analysis.

- CONTRACTOR REPORT. Scientific and technical findings by NASA-sponsored contractors and grantees.
- CONFERENCE PUBLICATION. Collected papers from scientific and technical conferences, symposia, seminars, or other meetings sponsored or cosponsored by NASA.

- SPECIAl PUBLICATION. Scientific, technical, or historical information from NASA programs, projects, and missions, often concerned with subjects having substantial public interest.

- TECHNICAL TRANSLATION. Englishlanguage translations of foreign scientific and technical material pertinent to NASA's mission.

Specialized services that complement the STI Program Office's diverse offerings include creating custom thesauri, building customized data bases, organizing and publishing research results ... even providing videos.

For more information about the NASA STI Program Office, see the following:

- Access the NASA STI Program Home Page at http://wwwo.sti.nasa.gov

- E-mail your question via the Internet to help@sti.nasa.gov

- Fax your question to the NASA Access Help Desk at (301) 621-0134

- Telephone the NASA Access Help Desk at (301) 621-0390

- Write to: NASA Access Help Desk NASA Center for AeroSpace Information 7121 Standard Drive

Hanover, MD 21076 

NASA/TM-2000-209777

\section{LWC and Temperature Effects on Ice Accretion Formation on Swept Wings at Glaze Ice Conditions}

Mario Vargas

Glenn Research Center, Cleveland, Ohio

Eli Reshotko

Case Western Reserve University, Cleveland, Ohio

Prepared for the

38th Aerospace Sciences Meeting and Exhibit

sponsored by the American Institute of Aeronautics and Astronautics

Reno, Nevada, January 10-13, 2000

National Aeronautics and

Space Administration

Glenn Research Center 



\section{Acknowledgments}

The authors would like to thank Mr. William Sexton and all of the personnel at the Icing Research Tunnel for their help in all phases of the experiment; Mr. Richard Czentorycki for his help with the drawings; and the personnel of the Imaging Technology Center for their assistance with the photographic work.

Available from

NASA Center for Aerospace Information 7121 Standard Drive Hanover, MD 21076

Price Code: A03
National Technical Information Service 5285 Port Royal Road Springfield, VA 22100

Price Code: A03 



\title{
LWC AND TEMPERATURE EFFECTS ON ICE ACCRETION FORMATION ON SWEPT WINGS AT GLAZE ICE CONDITIONS
}

\author{
Mario Vargas* \\ NASA Glenn Research Center, Cleveland, Ohio \\ and \\ Eli Reshotko ${ }^{\dagger}$ \\ Case Western Reserve University, Cleveland, Ohio
}

\begin{abstract}
An experiment was conducted to study the effect of liquid water content and temperature on the critical distance in ice accretion formation on swept wings at glaze ice conditions. The critical distance is defined as the distance from the attachment line to the beginning of the zone where roughness elements develop into glaze ice feathers. A baseline case of $150 \mathrm{mph}, 25^{\circ} \mathrm{F}, 0.75$ $\mathrm{g} / \mathrm{m}^{3} \mathrm{LWC}$ and $20 \mu \mathrm{m}$ MVD was chosen. Icing runs were performed on a NACA 0012 swept wing tip at $150 \mathrm{mph}$ and MVD of $20 \mu \mathrm{m}$ for liquid water contents of $0.5 \mathrm{~g} / \mathrm{m}^{3}, 0.75 \mathrm{~g} / \mathrm{m}^{3}$, and $1.0 \mathrm{~g} / \mathrm{m}^{3}$, and for total temperatures of $20^{\circ} \mathrm{F}, 25^{\circ} \mathrm{F}$ and $30^{\circ} \mathrm{F}$. At each tunnel condition, the sweep angle was changed from $0^{\circ}$ to $45^{\circ}$ in $5^{\circ}$ increments. Casting data, ice shape tracings, and close-up photographic data were obtained. The results showed that decreasing the LWC to $0.5 \mathrm{~g} / \mathrm{m}^{3}$ decreases the value of the critical distance at a given sweep angle compared to the baseline case, and starts the formation of complete scallops at $30^{\circ}$ sweep angle. Increasing the LWC to $1.0 \mathrm{~g} / \mathrm{m}^{3}$ increases the value of the critical distance compared to the baseline case, the critical distance remains always above 0 millimeters and complete scallops are not formed. Decreasing the total temperature to $20^{\circ} \mathrm{F}$ decreases the critical distance with respect to the baseline case and formation of complete scallops begins at $25^{\circ}$ sweep angle. When the total temperature is

\footnotetext{
Aerospace Engineer, Icing Branch, NASA Glenn Research Center, Member AIAA Engineering, Fellow AIAA
}

$\dagger$ Professor, Department of Mechanical and Aerospace

Copyright (c) 2000 by the American Institute of Aeronautics and Astronautics, Inc. No copyright is asserted in the United States under Title 17, U.S. Code. The U.S. Government has a royaltyfree license to exercise all rights under the copyright claimed herein for Governmental Purposes. All other rights are reserved by the copyright owner.
\end{abstract}

increased to $30^{\circ} \mathrm{F}$, bumps covered with roughness elements appear on the ice accretion at $25^{\circ}$ and $30^{\circ}$ sweep angles, large ice structures appear at $35^{\circ}$ and $40^{\circ}$ sweep angles, and complete scallops are formed at $45^{\circ}$ sweep angle.

\section{Nomenclature}

$\begin{array}{ll}A & \text { Sweep angle, degrees } \\ d_{c r} & \text { Critical distance, millimeters } \\ L W C & \text { Cloud liquid water content, } \mathrm{g} / \mathrm{m}^{3} \\ M V D & \text { Water droplet median volume diameter, } \\ & \mu \mathrm{m} \\ r & \text { Leading edge radius of airfoil, } \mathrm{m} \\ s & \text { Distance from the attachment line, } \\ & \text { millimeters } \\ T & \text { Total temperature, }{ }^{\circ} \mathrm{F} \\ \tau & \text { Ice accretion time, minutes } \\ V_{\infty} & \text { Free stream velocity, } \mathrm{m} / \mathrm{s}\end{array}$

\section{Introduction}

Ice accretions on swept wings at glaze ice conditions can be classified as complete scallops, incomplete scallops, or no-scallops. Complete scallops or lobster tails are ice accretions that appear only on swept wings for certain conditions that favor glaze ice formations and are characterized by the presence of scallop tips extending from the attachment line. The scallop tips have a particular shape, height, and spacing. Incomplete scallops are ice shapes that also appear only on swept wings and where scallops tips form beginning at a given distance from the attachment line. No-scallops are ice accretions where no scallop tips develop. An understanding of the fundamental physical mechanisms and parameters involved in their formation is one of the areas of research in the Icing Branch at NASA Glenn Research Center. These studies of ice accretion formations on swept wings are needed to provide the fundamental data and physical 
understanding for the development of models that can be implemented into 3D ice accretion codes.

This report presents the results of an experimental investigation carried out in the Icing Research Tunnel (IRT) at NASA Glenn Research Center to study the effect of LWC and temperature on the critical distance $d_{c r}$. Icing runs were conducted using a NACA 0012 swept wing tip. A baseline case ( $150 \mathrm{mph}, 25^{\circ} \mathrm{F}, 0.75 \mathrm{~g} / \mathrm{m}^{3} \mathrm{LWC}$ and $20 \mu \mathrm{m}$ MVD) used in previous experiments was chosen to study the effect of LWC and temperature on the critical distance. Starting from the baseline case icing runs were conducted at liquid water contents of $0.5 \mathrm{~g} / \mathrm{m}^{3}, 0.75 \mathrm{~g} / \mathrm{m}^{3}$, and $1.0 \mathrm{~g} / \mathrm{m}^{3}$, and temperatures of $20^{\circ} \mathrm{F}, 25^{\circ} \mathrm{F}$, and $30^{\circ} \mathrm{F}$ with other conditions the same as the baseline case. At each tunnel condition, the sweep angle was changed from $0^{\circ}$ to $45^{\circ}$ in $5^{\circ}$ increments. During the experiments, observations were also made of the ice accretions formed on the end cap of the airfoil. These observations allowed study of the growth of roughness elements into glaze ice feathers with a preferred direction of growth, and the formation of scallops at high local sweep angles.

The presence of scallop formations on swept wings has been documented in past studies of ice accretions on swept wings ${ }^{1,2,3}$. Initial work to predict scallop formations using a 3D ice accretion code was done by Reehorst ${ }^{4}$. LEWICE 3D was modified and code predictions were compared to ice accretion flight data. Reehorst and Bidwell did an experiment in the NASA Glenn Icing Research Tunnel (IRT) to study the effect of tunnel parameters on the presence or absence of scallops. Hedde and Guffond ${ }^{6}$ proposed a ballistic model of scallop growth.

A study of the fundamental physical mechanisms that lead to the formation of scallops on swept wings was conducted by Vargas and Reshotko ${ }^{7}, 8$. We studied the formation of scallops on a NACA 0012 swept wing tip at $45^{\circ}, 30^{\circ}$, and $15^{\circ}$ sweep angles. We chose a baseline case and obtained direct measurements of scallop height and spacing, castings, video data and close-up photographic data. Our results showed that scallops and incomplete scallops are made of glaze ice feathers that grow from roughness elements that have reached a minimum height and are located beyond a given distance from the attachment line. This distance, called the critical distance $d_{c r}$, was found to depend on tunnel conditions and sweep angle for the airfoil tested. It determines (together with the shape of the external streamlines) if complete scallops, incomplete scallops or no-scallops are going to be formed. We also identified the mechanisms of growth for complete and incomplete scallops, studied the effect of velocity, temperature and LWC on scallop formation, and examined the possibility that cross flow instability may be the physical mechanism that triggers the growth of roughness elements into glaze ice feathers in scallop formation.

A parametric experimental study on the effect of velocity and sweep angle on the critical distance $\mathrm{d}_{\mathrm{cr}}$ was conducted by Vargas and Reshotko ${ }^{9}$. Our results showed that at a given velocity and tunnel condition, as the sweep angle is increased from $0^{\circ}$ to $25^{\circ}$, the critical distance slowly decreases. As the sweep angle is increased past $25^{\circ}$, the critical distance starts decreasing more rapidly. For 75 and $100 \mathrm{mph}$ it reaches a value of 0 millimeters at $35^{\circ}$. For 150 and $200 \mathrm{mph}$ it reaches a value of 0 millimeters at $40^{\circ}$. On the ice accretion, as the sweep angle is increased from $0^{\circ}$ to $25^{\circ}$, the extent of the attachment line zone slowly decreases, and in the glaze ice feathers zone, the angle that the preferred direction of growth of the feathers makes with respect to the attachment line direction increases. But overall, the ice accretions remain similar to the $0^{\circ}$ sweep angle case. As the sweep angle is increased above $25^{\circ}$, the extent of the attachment line zone decreases rapidly and complete scallops form at $35^{\circ}$ sweep angle for 75 and $100 \mathrm{mph}$, and at $40^{\circ}$ for 150 and $200 \mathrm{mph}$.

The present work continues the parametric experimental investigation with the study of the effect of LWC and temperature. This research is needed in order to gain an understanding of the physical mechanisms involved in the formation of the critical distance.

\section{Background}

Previous studies on formation of ice accretions on swept wings at glaze ice conditions ${ }^{7,8}$ found that scallop and incomplete scallop formation is governed by local effects on roughness elements. Roughness elements formed at the beginning of the ice accretion process develop into glaze ice feathers when they reach a given height, and are located beyond a given distance from the attachment line. This distance is called the critical distance $d_{c r}$, and it depends on sweep angle and tunnel conditions (figure 1a). When the critical distance is not zero it defines two zones on the ice accretion. A zone called the attachment line zone, where the roughness elements do not become feathers, and another zone called the glaze ice feathers zone where the roughness elements develop 
into feathers (figures 1b). The attachment line zone begins at the attachment line proper and extends on each side to the location where roughness elements develop into feathers (beginning of the glaze ice feathers zone). The glaze ice feathers zone begins at the end of the attachment line zone and extends some distance chordwise. Only feathers that are an active part of the main ice accretion are included in the definition of the glaze ice feathers zone. When the critical distance is zero only the glaze ice feathers zone is present.

The feathers in the glaze ice feathers zone are inclined into the flow (figure 2). They have a tooth shape, and therefore a preferred direction of growth (the direction along which a 'feather is growing faster laterally, that is, the direction of the larger axis for the tooth shape of the top of the feather). The preferred direction of growth is oriented perpendicular to the external streamlines. The angle that the preferred direction of growth makes with respect to the attachment line direction is $90^{\circ}$ for feathers located on the attachment line (streamlines are parallel to the attachment line direction at this location). The angle decreases as the distance from the attachment line increases (the streamlines are turning as they move away from the location of the attachment line).

Three types of ice accretions were identified on swept wings at glaze ice conditions: complete scallops, incomplete scallops, and no-scallops.

When complete scallops form (figure 3 ), the ice accretion is covered with glaze ice feathers with a preferred direction of growth that is perpendicular to the external streamlines. The feathers have developed from roughness elements that reached a certain height. The value of the critical distance is zero, and only the glaze ice feathers zone is present. The feathers join along the preferred direction of growth to form ridges, with incipient scallop tips formed by the feathers at the end of each ridge. As the ridges grow they form scallop tips. The scallop tips have different inclinations with respect to the surface of the airfoil. Because of their different inclinations, as the scallop tips grow in height and along the preferred direction, they merge with adjacent scallop tips by joining at the top of the feathers that form each scallop tip. This mechanism is responsible for the growth of the scallop tips, their increase in size, and the enhancing of the spacing between scallops. Along the attachment line area the feathers tend to join other feathers around them by touching, bridging and filling, in this way they form areas of solid ice that are also covered with roughness elements. As the scallop tips grow by joining at their tops, the top surface tends to fill with water and areas of solid ice can be observed with roughness elements present.

When the critical distance is not zero and only roughness elements located beyond a given distance from the attachment line grow to become feathers, incomplete scallops or no-scallops may develop. The formation of incomplete scallops or no-scallops depends on the angle that the preferred direction of growth of the feathers makes with respect to the attachment line direction.

When incomplete scallops form (figure 4), the feathers in the glaze ice feathers zone will form scallop tips. The mechanisms of formation of these scallop tips were found to be identical to the mechanisms observed for the formation of the scallop tips in the complete scallop case. The formation of the scallop tips depends on the angle that the preferred direction of growth of the feathers makes with respect to the attachment line, which in turn depends on the distance from the attachment line at which those feathers are located. The angle must be large enough to allow the mechanisms of formation of scallop tips to operate and form scallop tips, and also must be large enough to prevent the ice of the attachment line zone from covering all the glaze ice feathers zone and burying the incipient scallop tips.

When no-scallops form (figure 5), scallop tips are not present in the ice accretion. Three situations may lead to the formation of no-scallops. In one case the critical distance may be so large that only the attachment line zone is present. In the second case the attachment line zone and the glaze ice feathers zone are both present, but the angle of the feathers with respect to the attachment line direction is not large enough for the mechanisms of formation of scallop tips to operate. In the last case, the attachment line zone and the glaze ice feathers zone are both present, and the angle of the feathers with respect to the attachment line direction is large enough for the mechanisms of scallop tip formation to operate, but not large enough to prevent the ice of the attachment line from totally covering the scallop tips. When the feathers are totally covered they cease to play a role in the formation of the ice accretion.

When the attachment line zone and the glaze ice feathers zone are both present, in general one will tend to prevail over the other in the first stages of the formation of the ice accretion, and this will influence the final ice shape. This interaction between the ice of the attachment line zone and the feathers in the 
glaze ice feathers zone depends on how fast each kind of ice grows. In an incomplete scallop when the critical distance is small and the feathers in the glaze ice feathers zone grow faster than the ice of the attachment line, they will form large scallop tips. As ice accretion time increases the lange scallop tips wash out the presence of the attachment line zone and the ice accretion looks almost like complete scallops. In a no-scallop, in some cases the feathers may grow faster than the attachment line ice in the beginning of the ice accretion, but the ice of the attachment line eventually will cover them and the feathers will cease to play a role in the formation of the ice shape. Because of the fast growth of the feathers in the initial stage of the formation of the ice accretion, the ice shape will show homs, and resemble some of the ice shapes that are observed in $2 \mathrm{D}$ ice accretions.

In all cases of formation of glaze ice accretions on a swept wing, the distance from the attachment line beyond which the roughness elements become glaze ice feathers (the critical distance $d_{c r}$ ) is a critical factor in the kind of ice accretion that will form.

The critical distance was found to be repeatable and fairly constant along the span of the airfoil. This suggests that after the roughness elements reach a certain size, a physical mechanism or a combination of physical mechanisms is causing some heat enhancement that triggers the roughness elements beyond a given distance from the attachment line to grow into small feathers to a height at which the flow field and the heat transfer on the element protruding into the flow keep the feather growing in height and with a preferred direction. It is not known if the mechanism or mechanisms initiate the growth in the preferred direction or if they only trigger the roughness elements to grow into glaze ice feathers. The unknown physical mechanisms appear to act only in the beginning of the ice accretion process, depend on tunnel conditions, and show a very strong dependence on the sweep angle.

Sweep angle and velocity have a strong effect on the critical distance. A parametric experimental study ${ }^{9}$ found that at given velocity and tunnel conditions, as the sweep angle is increased from $0^{\circ}$ to $25^{\circ}$, the critical distance slowly decreases. As the sweep angle is increased past $25^{\circ}$, the critical distance begins decreasing rapidly. Between $0^{\circ}$ and $25^{\circ}$ sweep angle, the angle that the preferred direction of growth of the feathers makes with respect to the attachment line direction slowly increases, but overall, the ice accretions remain similar to the $0^{\circ}$ sweep angle case.
Between $30^{\circ}$ and $45^{\circ}$ sweep angles, incomplete and complete scallops appear, and the ice accretions are different from the $0^{\circ}$ sweep angle case.

The change in the critical distance with the sweep angle, and the observation of the corresponding ice accretions, indicated that the basic mechanism that is triggering the growth of the roughness elements into feathers seems to operate up to about $25^{\circ}$ sweep angle. At this sweep angle there is noticeable change indicated by the rapid decrease of the critical distance. Either the mechanism operating before is enhanced or a new mechanism comes into play and this leads to the triggering into feathers of the roughness elements closer and closer to the attachment line.

The boundary layer cross flow instability mechanism has been suggested as a possible physical mechanism operating past $25^{\circ}$ sweep angle ${ }^{7,8,9}$ The observed change in the critical distance with sweep angle is consistent with calculations of stationary cross flow instability for a NACA 0012 airfoil $^{10,11}$.

Experimental studies on the dependence of the critical distance $d_{C r}$ on LWC and temperature are needed to gain understanding of the physical mechanisms that determine it, and to predict the kind of ice accretion that will form on an airfoil at a given set of tunnel conditions.

\section{Experimental Procedure}

\section{Icing Research Tunnel}

Figure 6 shows the Icing Research Tunnel. The IRT is a closed-loop refrigerated wind tunnel with a test section 1.8 meters ( 6 feet) high, 2.7 meters $(9$ feet) wide and 6.0 meters (20 feet) long. The total air temperature in the test section can be varied between $-30^{\circ} \mathrm{C}\left(-20^{\circ} \mathrm{F}\right)$ and $+1{ }^{\circ} \mathrm{C}\left(+33^{\circ} \mathrm{F}\right)$ within $\pm 0.5^{\circ} \mathrm{C}\left( \pm 1^{\circ} \mathrm{F}\right)$. Velocities up to $160 \mathrm{~m} / \mathrm{s}(350$ $\mathrm{mph}$ ) can be obtained with a blockage of $5 \%$ in the test section. A spray system allows control of the liquid water content (LWC) between 0.2 to 3.0 grams per cubic meter. The spray nozzles provide droplet median volume diameters (MVD) from 15 to $40 \mu \mathrm{m}$.

\section{Model}

The model chosen for this study was a NACA 0012 swept wing tip (figure 7). The airfoil is made of wood, with a 0.381 meter (15 inch) chord 
measured normal to the leading edge, and a 0.609 meter (24 inch) span. It is mounted in the tunnel on a stand that allows pivoting of the airfoil to sweep angles of $0^{\circ}$ to $45^{\circ}$ in $5^{\circ}$ increments. The end of the airfoil is fitted with a rounded end cap. For sweep angles larger than $30^{\circ}$ a small extension was fitted at the base of the airfoil to improve the airflow. A heater was installed on the area where the measurements and collection of ice shapes were going to be performed. The heater was powered by a $28 \mathrm{DC}, 1 \mathrm{amp}$, power supply. A rheostat between the power supply and the heater was used to control the temperature. A grid was painted on the surface of the heater to allow identification of the flow direction on the photographic data and to serve as a distance scale in some pictures.

\section{Castings}

For each one of the NACA 0012 icing runs, a urethane casting was made of the ice shape. The castings allowed measurement of the critical distance and observation of the ice accretion.

The castings were made by removing the ice shape from the airfoil using the heater, immersing the ice shape in a bath of bees-wax at $150^{\circ} \mathrm{F}$ to form a wax mold, draining the water from inside the wax mold, and filling the mold with liquid urethane. The urethane was allowed to solidify, and then a solvent was used to remove the wax. Figure 8 shows a urethane casting of an ice accretion.

\section{Icing Measurements}

For each run, a set of measurements was also taken directly on the ice shape. The height of the ice accretion was measured at the attachment line location, the critical distance was measured, and a pencil tracing of the ice shape was made, always at the same location on the airfoil.

\section{Test Matrix for Icing Runs}

Table 1 lists the test matrix employed for the icing runs of the baseline case. Table 2 lists the test matrix for the icing runs conducted to study the LWC and temperature effects.

\section{Test Procedure}

At the start of each run, the tunnel was brought to the target velocity and total temperature and the tunnel spray system was started. During the run the tunnel parameters were recorded using the NASA-Glenn Escort data acquisition system. Once the target ice accretion time was reached, the tunnel was brought to idle. After entering the tunnel, a measuring tape was placed around the ice shape, and photographic data were taken with a $35 \mathrm{~mm}$ camera following a predetermined sequence and location for the pictures. Then three cuts were made on the ice accretion to prepare the ice shape for removal. Following this, the icing measurements discussed above were taken directly on the ice accretion and general observations were recorded. The heater was activated and two samples of the ice shape were removed taking special care not to melt or damage the ice shape in the process. The removed ice shapes were taken to the casting area and bees-wax molds were made. The airfoil was cleaned before the next run.

\section{Results and Discussion}

Effect of Sweep Angle for a LWC of $0.75 \mathrm{~g} / \mathrm{m}^{3}$ and Total Temperature of $25^{\circ} \mathrm{F}$ (baseline case)

For a velocity of $150 \mathrm{mph}$, icing runs were carried out at sweep angles from $0^{\circ}$ to $45^{\circ}$ in $5^{\circ}$ increments. For each sweep angle casting data and photographic data were obtained and the critical distance was measured from them. In figure 9, the critical distance in millimeters is plotted against sweep angle in degrees. Measurements from the photographic data and the casting data are presented. Between $0^{\circ}$ and $25^{\circ}$ the critical distance decreases slowly from about 11.5 millimeters to about 10 millimeters. Between $25^{\circ}$ and $40^{\circ}$ the critical distance decreases rapidly and reaches a value of 0 millimeters (complete scallop case) at $40^{\circ}$, and it remains at 0 millimeters for a sweep angle of $45^{\circ}$.

For a sweep angle of $0^{\circ}$ (figure 10), the 2D case, the attachment line zone (we are keeping the nomenclature used for the swept wing case although in the 2D case there is no attachment line proper but a stagnation line) and the glaze ice feathers zone can be observed. The ice of the attachment line is covered with roughness elements and it is covering the feathers in the glaze ice feathers zone. On figure 10 , the glaze ice feathers zone can be observed because of the transparency of the ice covering the feathers, but the separation between the two zones is barely visible. A side view of the ice accretion (figure 11) shows that the ice of the attachment line zone has covered the top of the feathers, has spilled over them and is covering most of their sides. Because the sweep angle is $0^{\circ}$, the preferred direction of growth of the feathers (which is normal to the 
streamline direction) is oriented parallel to the stagnation line direction. The physical mechanisms of scallop tip formation cannot operate, no scallop tips are formed, and the resulting ice shape is a noscallop. At sweep angles of $5^{\circ}$ and $10^{\circ}$ (figure 12) the ice accretion is similar to the $0^{\circ}$ case. The angle that the preferred direction of growth of the feathers makes with respect to the attachment line direction is still not lange enough to allow the physical mechanisms of scallop tip formation to fully operate, or to prevent the ice of the attachment line zone from totally covering the feathers (figure 13). The resulting ice shape is a no-scallop. The same situation occurs at sweep angles of $15^{\circ}$ and $20^{\circ}$. At $25^{\circ}$ the angle that the preferred direction of growth of the feathers makes with respect to the attachment line direction is large enough to allow the mechanisms of formation of scallop tips to occur. The angle is also large enough so that the ice of the attachment line cannot totally cover the feathers. The resulting ice shape shows scallop tips and is an incomplete scallop (figures 14 and 15). At $30^{\circ}$ and $35^{\circ}$ sweep angles the ice shapes show a decrease in the extent of the attachment line zone (figure 16), and scallop tips that are better defined and developed. At $40^{\circ}$ sweep angle the critical distance is zero millimeters and the ice shape (figure 17 ) is a complete scallop. For $45^{\circ}$ sweep angle the ice shape is a complete scallop.

\section{Effect of Lowering the LWC to $0.5 \mathrm{~g} / \mathrm{m}^{3}$}

For a LWC to $0.5 \mathrm{~g} / \mathrm{m}^{3}$, while maintaining the other conditions the same as the baseline case, icing runs were carried out at sweep angles from $0^{\circ}$ to $45^{\circ}$ in $5^{\circ}$ increments. For each sweep angle casting data and photographic data were obtained and the critical distance was measured from them. In figure 18 the critical distance in millimeters is plotted against sweep angle in degrees. Measurements from the photographic data are presented. Between $0^{\circ}$ and $15^{\circ}$ the critical distance decreases slowly from about 11.5 millimeters to about 10.5 millimeters. Between $15^{\circ}$ and $30^{\circ}$ the critical distance decreases rapidly and reaches a value of 0 millimeters (complete scallop case) at $30^{\circ}$, and it remains at 0 millimeters for sweep angles of $35^{\circ}, 40^{\circ}$, and $45^{\circ}$. Comparison with the results for the baseline case shows that between $0^{\circ}$ and $15^{\circ}$ the critical distance for the lower LWC is close to the critical distance for the baseline case. After a sweep angle of $15^{\circ}$ there is a clear difference in the behavior of the critical distances as the sweep angle is increased. The critical distance for the lower LWC decreases rapidly to a value of 0 millimeters at $30^{\circ}$ sweep angle. In contrast, the critical distance for the baseline case decreases slowly until about $25^{\circ}$ and then collapses rapidly to a value of 0 millimeters at $40^{\circ}$ sweep angle. For the baseline case and the lower LWC case, once the critical distance has decreased to 0 millimeters (complete scallop), it remains at that value for larger values of the sweep angle. The overall effect of decreasing the LWC from $0.75 \mathrm{~g} / \mathrm{m}^{3}$ (the baseline case) to $0.5 \mathrm{~g} / \mathrm{m}^{3}$ has been the decrease in the value of the critical distance at a given sweep angle for sweep angles between $15^{\circ}$ and $40^{\circ}$, and the formation of complete scallops beginning at lower values of the sweep angle.

The casting and photographic data allow observation of the overall change of the ice accretion as the sweep angle is increased. At a sweep angle of $0^{\circ}$ (figure 19) the attachment line zone and the glaze ice feathers zone can be observed. The attachment line zone is covered with roughness elements, with large and small elements mixed together. No areas without roughness elements are observed. A narrow cavity running along the stagnation line can be observed; this feature is confirmed by observation of the casting of the ice accretion. The tops of the feathers in the glaze ice feather zone can be seen. Figure 20 shows a side view of the ice accretion with the stagnation line at the location where the measuring tape changes from black to yellow. The attachment line ice covers the tops of the feathers in the glaze ice feathers zone and spills over the side of the feathers. The feathers show a preferred direction oriented parallel to the stagnation line. As the sweep angle is increased to $5^{\circ}, 10^{\circ}, 15^{\circ}$, and $20^{\circ}$ the extent of the attachment line zone decreases but the ice accretions remain failly similar to the $0^{\circ}$ sweep angle case. No formation of scallop tips is observed at those sweep angles. Figures 21 and 22 show a front and a side view of the ice accretion for $20^{\circ}$ sweep angle. When the sweep angle is increased to $25^{\circ}$ the extent of the attachment line zone decreases and the ice accretion shows the formation of scallop tips (figures 23 and 24). For $30^{\circ}$ sweep angle, large feathers appear along the attachment line area (figure 25). Only the top of the feathers can be observed (figure 26), the space between them is filled by ice with roughness elements. Other areas of the ice accretion are covered with glaze ice feathers and the ice accretion is a complete scallop. As the sweep angle is increased to $35^{\circ}, 40^{\circ}$, and $45^{\circ}$ the ice accretions become complete scallops with large glaze feathers along the attachment line (figures 27 and 28). The large feathers along the attachment line become better defined and the space between them is less filled with ice as the sweep angle is increased.

Figure 29 shows the casting data at sweep angles of $0^{\circ}, 10^{\circ}, 20^{\circ}$, and $25^{\circ}$ for the baseline case (LWC of $0.75 \mathrm{~g} / \mathrm{m}^{3}$ ), and for the case with LWC of $0.5 \mathrm{~g} / \mathrm{m}^{3}$. The ice accretions for the low LWC case are smaller 
in size because the mass flux of water is lower at the low LWC.

\section{Effect of Increasing the LWC to $1.0 \mathrm{~g} / \mathrm{m}^{3}$}

For a LWC of $1.0 \mathrm{~g} / \mathrm{m}^{3}$, while maintaining the other conditions the same as the baseline case, icing runs were carried out at sweep angles from $0^{\circ}$ to $45^{\circ}$ in $5^{\circ}$ increments. For each sweep angle, casting data and photographic data were obtained and the critical distance was measured from them. On figure 30 the critical distance in millimeters is plotted against sweep angle in degrees. Measurements from the photographic data are presented. Between $0^{\circ}$ and $25^{\circ}$ the critical distance decreases slowly from about 12.5 millimeters to about $\mathbf{1 1 . 0}$ millimeters. Between $25^{\circ}$ and $45^{\circ}$ the critical distance decreases rapidly and reaches a value of 3 millimeters (incomplete scallop case) at $45^{\circ}$. Comparison with the results for the baseline case shows that between $0^{\circ}$ and $30^{\circ}$ the critical distance for the higher LWC is slightly higher than the critical distance for the baseline case. After a sweep angle of $30^{\circ}$ the critical distance for the baseline case decreases to a value of 0 millimeters (complete scallop), while the critical distance for the higher LWC case also decreases but remains at a value larger than 0 millimeters. The overall effect of increasing the LWC from $0.75 \mathrm{~g} / \mathrm{m}^{3}$ (the baseline case) to $1.0 \mathrm{~g} / \mathrm{m}^{3}$ is the increase in the value of the critical distance for sweep angles between $30^{\circ}$ and $45^{\circ}$, and the lack of development of complete scallops for all values of the sweep angle up to $45^{\circ}$.

Observation of the casting and photographic data allows study of the overall change of the ice accretion as the sweep angle is increased. At a sweep angle of $0^{\circ}$ (figure 31) the attachment line zone and the glaze ice feathers zone are present but they can barely be separated. The ice of that attachment line zone is covering the top of the feathers in the glaze ice feathers zone and the transparency of the ice allows observation of the tops of the covered feathers. The separation between the two zones can be observed in the casting data because they capture the change in the front surface of the ice accretion at the location where the glaze ice feathers zone begins. The casting data also capture the roughness elements covering the attachment line ice, which are not easily distinguished in the photographic data. A narrow cavity running along the stagnation line can be observed. As the sweep angle is increased to $5^{\circ}, 10^{\circ}$, and $15^{\circ}$ (figure 32), the extent of the attachment line zone slowly decreases but the ice accretions remain similar to the $0^{\circ}$ sweep angle case. Incipient scallop tips are observed at $20^{\circ}$ sweep angle, and they become more developed as the sweep angle is increased to $25^{\circ}$ and $30^{\circ}$ sweep angles (figure 33).
As the sweep angle is increased to $35^{\circ}, 40^{\circ}$, and $45^{\circ}$ (figures $34,35,36$ ) the extent of the attachment line zone decreases rapidly but without reaching a value of 0 millimeters. The ice accretion remains an incomplete scallop.

\section{Effect of Lowering the Temperature to $20^{\circ} \mathrm{F}$}

For a total temperature of $20^{\circ} \mathrm{F}$, while maintaining the other conditions the same as the baseline case, icing runs were carried out at sweep angles from $0^{\circ}$ to $45^{\circ}$ in $5^{\circ}$ increments. For each sweep angle casting data and photographic data were obtained and the critical distance was measured. On figure 37 the critical distance in millimeters is plotted against sweep angle in degrees. Measurements from the photographic data are presented. Between $0^{\circ}$ and $15^{\circ}$ the critical distance decreases from 7 millimeters to 6 millimeters. Between $15^{\circ}$ and $25^{\circ}$ the critical distance decreases rapidly and reaches a value of 0 millimeters (complete scallop case) at $25^{\circ}$, and it remains at 0 millimeters for sweep angles of $30^{\circ}, 35^{\circ}$, $40^{\circ}$, and $45^{\circ}$. Companison with the results for the baseline case shows that between $0^{\circ}$ and $15^{\circ}$ the critical distance for the lower temperature is smaller than the critical distance for the baseline case. After a sweep angle of $15^{\circ}$ there is a clear difference in the behavior of the critical distances as the sweep angle is increased. In the low temperature case, the critical distance rapidly reaches a value of 0 millimeters at $25^{\circ}$ sweep angle. In contrast, the critical distance for the baseline case decreases slowly until about $25^{\circ}$ and then decreases rapidly to a value of 0 millimeters at $40^{\circ}$ sweep angle. For the baseline case and the lower temperature case, once the critical distance has decreased to 0 millimeters (complete scallop), it remains at that value for larger values of the sweep angle. The overall effect of decreasing the total temperature from $25^{\circ} \mathrm{F}$ (the baseline case) to $20^{\circ} \mathrm{F}$ is the decrease of the value of the critical distance at a given sweep angle, and the formation of complete scallops beginning at lower values of sweep angle.

The casting and photographic data allow observation of the overall change of the ice accretion as the sweep angle is increased. At a sweep angle of $0^{\circ}$ (figure 38) the attachment line zone and the glaze ice feathers zone can be observed. Roughness elements, lange and small mixed together, cover the ice of the attachment line zone, no areas are observed without them. A narrow cavity running along the stagnation line can barely be observed in the photographic data, this feature is confirmed in the casting of the ice accretion. The ice of the attachment line zone is covering the top of some of the feathers in the glaze ice feathers zone (figure 39). As the sweep angle is increased to $5^{\circ}, 10^{\circ}, 15^{\circ}$, and 
$20^{\circ}$, the extent of the attachment line zone slowly decreases but the ice accretions remain similar to the $0^{\circ}$ sweep angle case (figure 40). As the sweep angle is increased to $25^{\circ}$ (figure 41) large feathers appear along the attachment line area, but the space between them and all or part of their tops are covered with ice making it difficult to observe them. Their top parts are better observed in the area of the airfoil just below the end cap as shown in figure 42 . Large feathers along the attachment line area can also be observed as the sweep angle is increased to $30^{\circ}$ (figure 43 ) $, 35^{\circ}, 40^{\circ}$, and $45^{\circ}$. With the increase in the sweep angle less ice is observed between the feathers and a larger part of them can be seen (figure 44). At $45^{\circ}$ the feathers are well defined and mesh well with the feathers away from the attachment line (figure 45). The ice accretions for sweep angles from $25^{\circ}$ to $45^{\circ}$ are complete scallops.

\section{Effect of Increasing the Temperature to $30^{\circ} \mathrm{F}$}

For a total temperature of $30^{\circ} \mathrm{F}$ while maintaining the other conditions the same as the baseline case icing runs were carried out at sweep angles from $0^{\circ}$ to $45^{\circ}$ in $5^{\circ}$ increments. For each sweep angle casting data and photographic data were obtained. No measurements of the critical distance are possible in this case. At this temperature it is not possible to distinguish the separation between the attachment line zone and glaze ice feathers zone.

Although the critical distance cannot be measured, the photographic and casting data allow observation of the overall change of the ice accretion as the sweep angle is increased. Significant understanding on the formation of the ice accretion can be obtained from studying the ice accretion formation on the end cap when the airfoil is set at sweep angle of $0^{\circ}$. Figure 46 shows a side view of the ice accretion on the end cap. The ice accretion changes as the local sweep angle on the end cap increases from $0^{\circ}$ at the beginning of the end cap, to about $73^{\circ}$ at the end tip. Although incipient scallops still form beginning at approximately $40^{\circ}$ sweep angle (figures 47 and 48), they are not well defined, particularly in the area where the local sweep angle changes from $40^{\circ}$ to about $55^{\circ}$. Up to local sweep angles of $70.5^{\circ}$, the feathers forming the ice accretion are distorted (figure 49), looking like 'blobs" of glaze ice. At local sweep angles above $70.5^{\circ}$ the feathers forming the scallops are less distorted (figure 50), very close to each other and growing perpendicular to the airfoil surface. The observations on the end cap indicate that for airfoil sweep angles between $0^{\circ}$ and $45^{\circ}$ we should expect glaze ice feathers in the ice accretion to be distorted and looking like "blobs" of glaze ice. This distortion of the glaze ice feathers makes it difficult to separate them from large bumps formed by attachment line ice. We should also expect that at any sweep angle where scallops are present they will not be well defined.

At a sweep angle of $0^{\circ}$ (figure 51) the ice accretion is made of clear ice covered with roughness elements with a narrow cavity running along the stagnation line. The attachment line zone is present, but it is not possible to determine how far it extends. After a distance of about 12 millimeters, the ice shows some bumps (figure 52). It is not possible to determine if those bumps are part of the attachment line ice or if they are distorted glaze ice feathers. This makes it impossible to establish the value of the critical distance. As the sweep angle is increased to $5^{\circ}, 10^{\circ}$, $15^{\circ}$ and $20^{\circ}$ the ice accretion remains similar to the $0^{\circ}$ sweep angle case. At $25^{\circ}$ and $30^{\circ}$ sweep angles the ice accretion shows a more uneven surface, and bumps covered with roughness elements appear on the surface of the ice (figures 53,54 ). As the sweep angle is increased to $35^{\circ}$ and $40^{\circ}$, larger ice structures appear on the surface of the ice (figure 55) that look like incipient not well defined scallops. At $45^{\circ}$ sweep angle the ice accretion shows scallops (figure 56). The scallops are not well defined, and are similar to the ones observed on the end cap when the airfoil was at $0^{\circ}$ sweep angle. Overall, the ice accretion begins to change (compared with the one at $0^{\circ}$ sweep angle) when the sweep angle goes past $25^{\circ}$. Initially the change consists of the appearance of bumps covered with roughness elements (at $25^{\circ}$ and $30^{\circ}$ sweep angles), and then larger ice structures that resemble scallops appear (at $35^{\circ}, 40^{\circ}$, and $45^{\circ}$ sweep angles).

\section{Summary and Conclusions}

An experiment was conducted to understand the effect of LWC and temperature on the critical distance. A baseline case of $150 \mathrm{mph}, 25^{\circ} \mathrm{F}, 0.75$ $\mathrm{g} / \mathrm{m}^{3} \mathrm{LWC}$ and $20 \mu \mathrm{m}$ MVD was used. Icing runs were conducted with a NACA 0012 swept wing tip at sweep angles from $0^{\circ}$ to $45^{\circ}$ in $5^{\circ}$ increments. The runs were conducted first at the baseline case, and then for LWCs of $0.5 \mathrm{~g} / \mathrm{m}^{3}$ and $1.0 \mathrm{~g} / \mathrm{m}^{3}$ (other conditions the same as the baseline case), and for total temperatures of $20{ }^{\circ} \mathrm{F}$ and $30{ }^{\circ} \mathrm{F}$ (other conditions the same as the baseline case). Ice shape tracings, photographic data, and casting data were obtained and from them values of the critical distance were measured. In addition, photographic data of ice accretions on the end cap of the airfoil were obtained. A grid was painted on the end cap of the airfoil to indicate the change in the local sweep angle. 
The experimental investigation showed that for the baseline case the critical distance decreases slowly between $0^{\circ}$ and $25^{\circ}$ sweep angles. Between $25^{\circ}$ and $40^{\circ}$ the critical distance decreases rapidly reaching a value of 0 millimeters (complete scallop) at $40^{\circ}$. The photographic data show that at $0^{\circ}$ sweep angle the ice of the attachment line zone is totally covering the feathers in the glaze ice feathers zone. As the sweep angle is increased from $5^{\circ}$ to $20^{\circ}$, the angle that the preferred direction of growth of the feathers makes with respect to the attachment line direction increases but is not enough to form incomplete scallops. Aside from the change in the angle of the preferred direction of growth of the feathers, the ice shape is basically similar to the $0^{\circ}$ sweep angle case. As the sweep angle is increased to $25^{\circ}$, the angle of the preferred direction of growth of the feathers is large enough to form incomplete scallops. At $30^{\circ}$ and $35^{\circ}$ the ice shape shows more defined scallop tips and a decrease in the extent of the attachment line. At $40^{\circ}$ and $45^{\circ}$ the ice shapes are complete scallops.

When the LWC is decreased to $0.5 \mathrm{~g} / \mathrm{m}^{3}$ the overall effect is the decrease in the value of the critical distance for sweep angles between $15^{\circ}$ and $40^{\circ}$ compared to the baseline case, and the formation of complete scallops beginning at $30^{\circ}$ sweep angle, earlier than for the baseline case. Between $0^{\circ}$ and $20^{\circ}$ sweep angles the ice accretion is a no scallop and remains similar to the $0^{\circ}$ sweep angle case. Scallop tips are observed for a sweep angle of $25^{\circ}$. Beginning at $30^{\circ}$ sweep angle large feathers are observed along the attachment line area.

When the $L W C$ is increased to $1.0 \mathrm{~g} / \mathrm{m}^{3}$ the overall effect is the increase in the value of the critical distance for sweep angles between $30^{\circ}$ and $45^{\circ}$ compared to the baseline case. The critical distance remains above 0 millimeters and complete scallops are not formed. As the sweep angle is increased between $0^{\circ}$ and $30^{\circ}$ the ice accretion remains similar to the $0^{\circ}$ sweep angle case. Scallop tips are observed at $25^{\circ}$ and $30^{\circ}$ sweep angles. The ice accretion remains an incomplete scallop at $35^{\circ}, 40^{\circ}$ and $45^{\circ}$ sweep angles.

When the total temperature is decreased to $20^{\circ} \mathrm{F}$, the critical distance decreases slowly between sweep angles of $0^{\circ}$ and $15^{\circ}$. As the sweep angle is increased to $20^{\circ}$ and $25^{\circ}$, the critical distance decreases rapidly and reaches a value of 0 millimeters at $25^{\circ}$. Between $0^{\circ}$ and $20^{\circ}$ the ice accretion remains similar to the $0^{\circ}$ sweep angle case. At $25^{\circ}$ sweep angle a complete scallop is formed. The ice accretion at this sweep angle shows large feathers along the attachment line area.

When the total temperature is increased to $30^{\circ} \mathrm{F}$ it is not possible to measure the critical distance on the ice accretion. At this temperature the glaze ice feathers get distorted, making it difficult to distinguish them from other glaze ice formations, and it is not possible to establish the location or presence of the glaze ice feathers zone. The casting and photographic data show that as the sweep angle is increased from $0^{\circ}$ and $20^{\circ}$ the ice accretions remain similar to the $0^{\circ}$ sweep angle case. At $25^{\circ}$ and $30^{\circ}$ sweep angles, bumps covered with roughness elements appear on the ice accretion. At $35^{\circ}$ and $40^{\circ}$ sweep angles larger ice structures appear on the ice, and at $45^{\circ}$ sweep angle large ice structures that resemble scallop formations are observed.

In previous investigations ${ }^{7,8}$ it was suggested that the strong dependence of scallop formation on sweep angle pointed towards the need to consider boundary layer instabilities as one of the physical mechanisms operating in the formation of scallops. The boundary layer instability mechanism that was proposed was the cross flow instability. The results of the past investigations showed that at $25^{\circ}$ sweep angle, either there is an enhancement of the physical mechanisms operating in the previous sweep angles, or a new mechanism or mechanisms start to come into play. This is specially seen in the rapid decrease in the extent of the attachment line zone and the eventual formation of complete scallops. The cross flow instability starts to be a factor in the transition of the boundary layer when the sweep angle of an airfoil is larger than about $25^{\circ}$. This seems to agree with the sweep angle at which the critical distance starts to decrease rapidly. The observed change in $d_{c r}$ is consistent with recent calculations of stationary cross flow instability for a NACA 0012 airfoil $^{10}$ providing good circumstantial support for the cross flow hypothesis. The results of the present investigation show that LWC and total temperature play a role in determining the critical distance. The reason why changes in LWC and total temperature affect the critical distance and the formation of ice accretions on swept wings is not known. It is possible that changes in the tunnel conditions affect the growth of the roughness elements in the initial stages of the formation of the ice accretion, and this affects the development of roughness elements into glaze ice feathers. Further research into the role that 
roughness elements play in the formation of ice accretions on swept wings at glaze ice conditions is needed.

The results of the present experimental investigation show that the critical distance is affected by changes in LWC and total temperature. The effect of those parameters should now be combined with the measured dependence of the critical distance on sweep angle at a given velocity observed in previous experiments. Additional research on roughness effects, attachment line ice growth, and glaze ice feathers growth, followed by flow field and heat transfer studies, are needed to identify and gain understanding of the physical mechanisms involved. In order to predict ice accretions on swept wings, an understanding of the effect of tunnel parameters on the critical distance is needed.

\section{Acknowledgements}

The authors would like to thank Mr. William Sexton and all of the personnel at the Icing Research Tunnel for their help in all phases of the experiment; Mr. Richard Czentorycki for his help with the drawings; and the personnel of the Imaging Technology Center for their assistance with the photographic work.

\section{References}

1 Wilder, R.W., "A Theoretical and Experimental Means to Predict Ice Accretion Shapes for Evaluating Aircraft Handling and Performance Characteristics", AGARD Report No. 127 (Aircraft (cing), Ottawa, Canada, 1977.

2

Pierre, M. and Vaucheret, $X$., "Icing Test Facilities and Test Techniques in Europe", AGARD Report No. 127 (Aircraft lcing), Ottawa, Canada, 1977.

${ }^{3}$ Laschka, B. and Jesse, R.E., "Ice Accretion and its Effects on Aerodynamics of Unprotected Aircraft Components", AGARD Report No. 127 (Aircraft lcing), Ottawa, Canada, 1977.

${ }^{4}$ Reehorst, A.L., "Prediction of Ice Accretion on a Swept NACA 0012 Airfoil and Comparisons to Flight Test Results", AIAA Paper 92-0043, Jan. 1992.

5 Reehorst, A.L. and Bidwell, C., NASA Lewis Research Center internal document, 1991.

${ }^{6}$ Hedde, T. and Guffond, D., "Improvement of the ONERA 3D lcing Code, Comparison with 3D
Experimental Shapes", AIAA Paper 93-0169, Jan. 1993.

7 Vargas, M. and Reshotko, E., "Physical Mechanisms of Glaze Ice Scallop Formations on Swept Wings", AlAA Paper 98-0491, Jan. 1998. NASA TM-1998-206616.

${ }^{8}$ Vargas, M., "Ice Accretion on Swept Wings at Glaze Ice Conditions", Ph.D. Thesis, Case Western Reserve University, Cleveland, Ohio, May 1998.

9 Vargas, M. and Reshotko, E., "Parametric Experimental Study of the Formation of Glaze Ice Shapes on Swept Wings", AlAA Paper 99-0094, Jan. 1999. NASA TM-1999-208900.

${ }^{10}$ Reshotko, E., Vargas, M. and Reed, H. L., "Ice Formation on Swept Wings - Relation to Cross Flow Instability?", Bull. APS, Vol. 43 No. 9, Nov. 1998, p. 1993.

11 Reshotko, E., Vargas, M. and Reed, H. L., "Relation of Glaze Ice Formations on Swept Wings to Cross Flow Instability", $5^{\text {th }}$ IUTAM Symposium on Laminar-Turbulent Transition, Sedona, $A Z$, Sept.1999. 


\begin{tabular}{|c|c|c|c|c|c|c|}
\hline Run Number & Sweep Angle & $\begin{array}{c}\text { Velocity } \\
(\mathrm{mph})\end{array}$ & $\begin{array}{c}\text { Temperature } \\
(\mathrm{F})\end{array}$ & $\begin{array}{c}\text { LWC } \\
\left(\mathrm{g} / \mathrm{m}^{3}\right)\end{array}$ & $\begin{array}{c}\text { MND } \\
(\mu \mathrm{m})\end{array}$ & $\begin{array}{c}\text { Ice Accretion } \\
\text { Time } \\
\text { (min) }\end{array}$ \\
\hline O33098.03 & $0^{\circ}$ & 150 & 25 & 0.75 & 20 & 5 \\
\hline O42998.01 & $0^{\circ}$ & 150 & 25 & 0.75 & 20 & 5 \\
\hline O42998.02 & $5^{\circ}$ & 150 & 25 & 0.75 & 20 & 5 \\
\hline O42998.03 & $10^{\circ}$ & 150 & 25 & 0.75 & 20 & 5 \\
\hline 042998.04 & $15^{\circ}$ & 150 & 25 & 0.75 & 20 & 5 \\
\hline 042998.05 & $20^{\circ}$ & 150 & 25 & 0.75 & 20 & 5 \\
\hline 042998.06 & $25^{\circ}$ & 150 & 25 & 0.75 & 20 & 5 \\
\hline 042998.07 & $30^{\circ}$ & 150 & 25 & 0.75 & 20 & 5 \\
\hline 042998.08 & $35^{\circ}$ & 150 & 25 & 0.75 & 20 & 5 \\
\hline 042998.09 & $40^{\circ}$ & 150 & 25 & 0.75 & 20 & 5 \\
\hline 042998.10 & $45^{\circ}$ & 150 & 25 & 0.75 & 20 & 5 \\
\hline 101498.10 & $30^{\circ}$ & 150 & 25 & 0.75 & 20 & 5 \\
\hline 101498.11 & $35^{\circ}$ & 150 & 25 & 0.75 & 20 & 5 \\
\hline 101498.12 & $40^{\circ}$ & 150 & 25 & 0.75 & 20 & 5 \\
\hline 101598.08 & $5^{\circ}$ & 150 & 25 & 0.75 & 20 & 5 \\
\hline 101598.09 & $10^{\circ}$ & 150 & 25 & 0.75 & 20 & 5 \\
\hline 101598.10 & $15^{\circ}$ & 150 & 25 & 0.75 & 20 & 5 \\
\hline 101598.11 & $20^{\circ}$ & 150 & 25 & 0.75 & 20 & 5 \\
\hline 101598.12 & $25^{\circ}$ & 150 & 25 & 0.75 & 20 & 5 \\
\hline
\end{tabular}

Table 1. Test Matrix for the baseline case 


\begin{tabular}{|c|c|c|c|c|c|c|}
\hline Run Number & Sweep Angle & $\begin{array}{l}\text { Velocity } \\
\text { (mph) }\end{array}$ & $\begin{array}{c}\text { Temperature } \\
\left.\text { ( }{ }^{\circ} \mathrm{F}\right)\end{array}$ & $\begin{array}{l}\text { LWC } \\
\left(\mathrm{g} / \mathrm{m}^{3}\right)\end{array}$ & $\begin{array}{l}\text { MND } \\
(\mu \mathrm{m})\end{array}$ & $\begin{array}{c}\text { Ice Accretion } \\
\text { Time } \\
\text { (min) }\end{array}$ \\
\hline 101698.00 & $5^{\circ}$ & 150 & 25 & 0.75 & 20 & 3 \\
\hline \multicolumn{7}{|l|}{ LWC effect } \\
\hline 101698.01 & $0^{\circ}$ & 150 & 25 & 0.50 & 20 & 5 \\
\hline 101698.02 & $5^{\circ}$ & 150 & 25 & 0.50 & 20 & 5 \\
\hline 101698.03 & $10^{\circ}$ & 150 & 25 & 0.50 & 20 & 5 \\
\hline 101698.04 & $15^{\circ}$ & 150 & 25 & 0.50 & 20 & 5 \\
\hline 101698.05 & $20^{\circ}$ & 150 & 25 & 0.50 & 20 & 5 \\
\hline 101698.06 & $25^{\circ}$ & 150 & 25 & 0.50 & 20 & 5 \\
\hline 101698.07 & $30^{\circ}$ & 150 & 25 & 0.50 & 20 & 5 \\
\hline 101698.08 & $35^{\circ}$ & 150 & 25 & 0.50 & 20 & 5 \\
\hline 101698.09 & $40^{\circ}$ & 150 & 25 & 0.50 & 20 & 5 \\
\hline 101698.10 & $45^{\circ}$ & 150 & 25 & 0.50 & 20 & 5 \\
\hline 101698.11 & $30^{\circ}$ & 150 & 25 & 1.00 & 20 & 5 \\
\hline 101698.12 & $5^{\circ}$ & 150 & 25 & 1.00 & 20 & 5 \\
\hline 101698.13 & $0^{\circ}$ & 150 & 25 & 1.00 & 20 & 5 \\
\hline 101698.14 & $10^{\circ}$ & 150 & 25 & 1.00 & 20 & 5 \\
\hline 101698.15 & $15^{\circ}$ & 150 & 25 & 1.00 & 20 & 5 \\
\hline 101998.A & $30^{\circ}$ & 200 & 25 & 0.75 & 20 & 2 \\
\hline 101998.B & $30^{\circ}$ & 200 & 25 & 0.75 & 20 & 8 \\
\hline \multicolumn{7}{|l|}{ LWC effect } \\
\hline 101998.01 & $20^{\circ}$ & 150 & 25 & 1.00 & 20 & 5 \\
\hline 101998.02 & $25^{\circ}$ & 150 & 25 & 1.00 & 20 & 5 \\
\hline 101998.03 & $35^{\circ}$ & 150 & 25 & 1.00 & 20 & 5 \\
\hline 101998.04 & $40^{\circ}$ & 150 & 25 & 1.00 & 20 & 5 \\
\hline 101998.05 & $45^{\circ}$ & 150 & 25 & 1.00 & 20 & 5 \\
\hline 101998.06 & $30^{\circ}$ & 150 & 25 & 1.00 & 20 & 5 \\
\hline \multicolumn{7}{|l|}{$\begin{array}{c}\text { Temperature } \\
\text { effect }\end{array}$} \\
\hline 101998.07 & $45^{\circ}$ & 150 & 20 & 0.75 & 20 & 5 \\
\hline 101998.08 & $40^{\circ}$ & 150 & 20 & 0.75 & 20 & 5 \\
\hline 101998.09 & $35^{\circ}$ & 150 & 20 & 0.75 & 20 & 5 \\
\hline 101998.10 & $30^{\circ}$ & 150 & 20 & 0.75 & 20 & 5 \\
\hline 101998.11 & $25^{\circ}$ & 150 & 20 & 0.75 & 20 & 5 \\
\hline 101998.12 & $20^{\circ}$ & 150 & 20 & 0.75 & 20 & 5 \\
\hline 101998.13 & $15^{\circ}$ & 150 & 20 & 0.75 & 20 & 5 \\
\hline 101998.14 & $10^{\circ}$ & 150 & 20 & 0.75 & 20 & 5 \\
\hline 101998.15 & $5^{\circ}$ & 150 & 20 & 0.75 & 20 & 5 \\
\hline 101998.16 & $0^{\circ}$ & 150 & 20 & 0.75 & 20 & 5 \\
\hline & & & & & & \\
\hline \multicolumn{7}{|l|}{$\begin{array}{c}\text { Temperature } \\
\text { effect }\end{array}$} \\
\hline 102098.01 & $0^{\circ}$ & 150 & 30 & 0.75 & 20 & 5 \\
\hline 102098.02 & $5^{\circ}$ & 150 & 30 & 0.75 & 20 & 5 \\
\hline 102098.03 & $10^{\circ}$ & 150 & 30 & 0.75 & 20 & 5 \\
\hline 102098.04 & $15^{\circ}$ & 150 & 30 & 0.75 & 20 & 5 \\
\hline 102098.05 & $20^{\circ}$ & 150 & 30 & 0.75 & 20 & 5 \\
\hline 102098.06 & $25^{\circ}$ & 150 & 30 & 0.75 & 20 & 5 \\
\hline 102098.07 & $0^{\circ}$ & 150 & 30 & 0.75 & 20 & 5 \\
\hline 102098.08 & $30^{\circ}$ & 150 & 30 & 0.75 & 20 & 5 \\
\hline 102098.09 & $35^{\circ}$ & 150 & 30 & 0.75 & 20 & 5 \\
\hline 102098.10 & $40^{\circ}$ & 150 & 30 & 0.75 & 20 & 5 \\
\hline 102098.11 & $45^{\circ}$ & 150 & 30 & 0.75 & 20 & 5 \\
\hline 102098.12 & $5^{\circ}$ & 75 & 25 & $0.75(0.80)$ & 20 & 5 \\
\hline 102098.13 & $10^{\circ}$ & 75 & 25 & 0.750 .801 & 20 & 5 \\
\hline & & & & & & \\
\hline & & & & & & \\
\hline & & & & & & \\
\hline & & & & & & \\
\hline
\end{tabular}

Table 2. Test Matrix for $L W C$ and temperature effect 


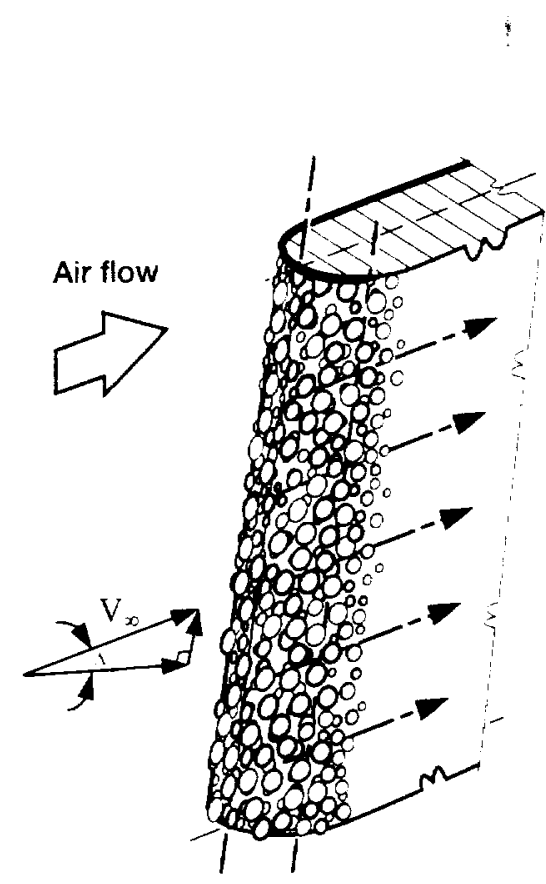

Roughness elements (a) develop on leading edge

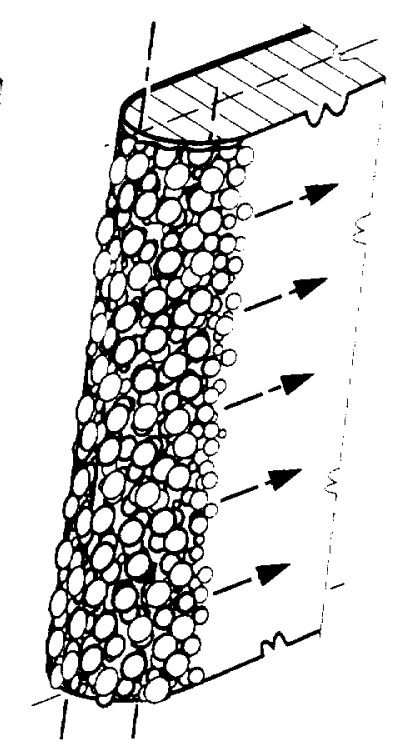

Roughness elements grow

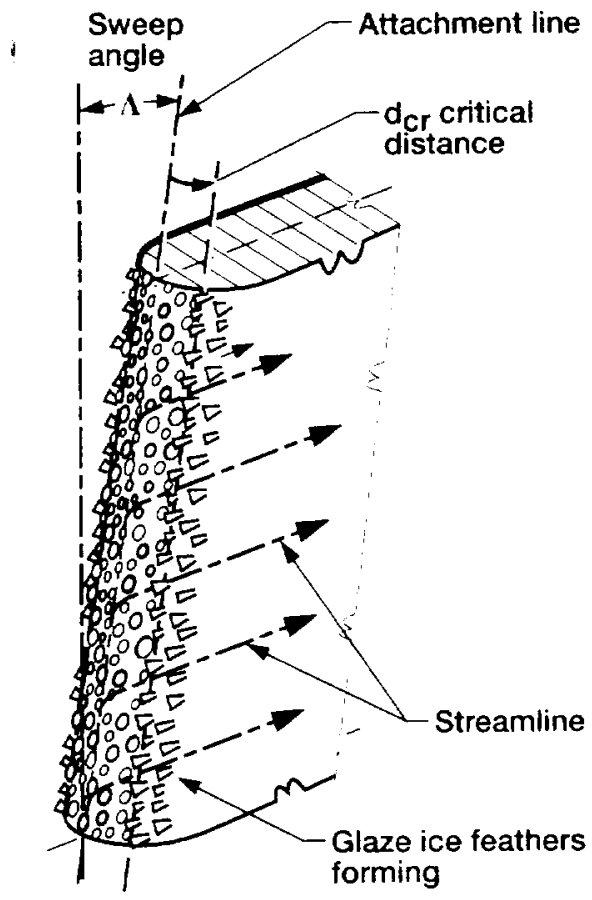

Roughness elements at a given distance trom the attachment line develop into glaze ice feathers

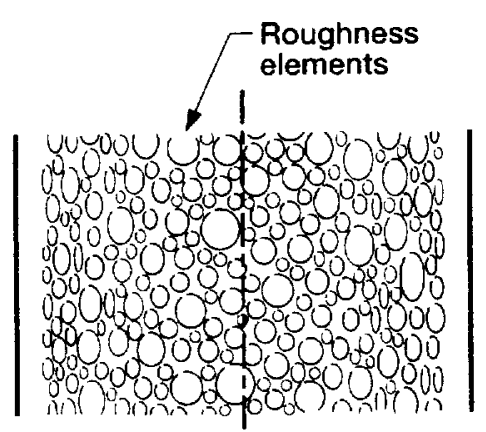

Roughness elements (b)

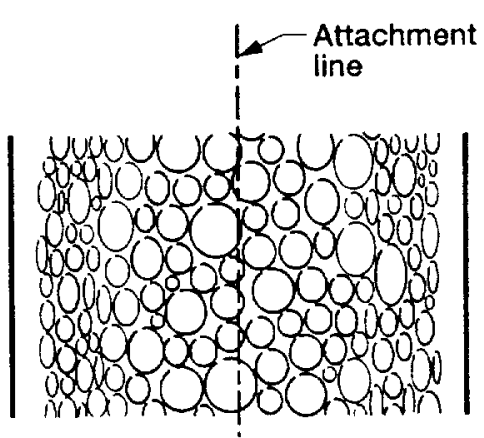

Roughness elements grow

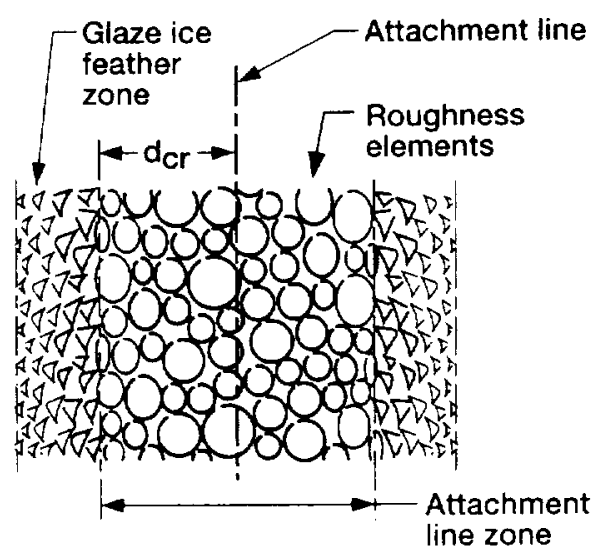

Roughness elements at a given distance from the attachment line develop into glaze ice feathers

Figure 1. Ice accretion on swept wing at glaze ice conditions. (a) Development of critical distance, $d_{a}$ (b) Attachment line zone and glaze ice feathers zone (view from direction normal to leading edge) 


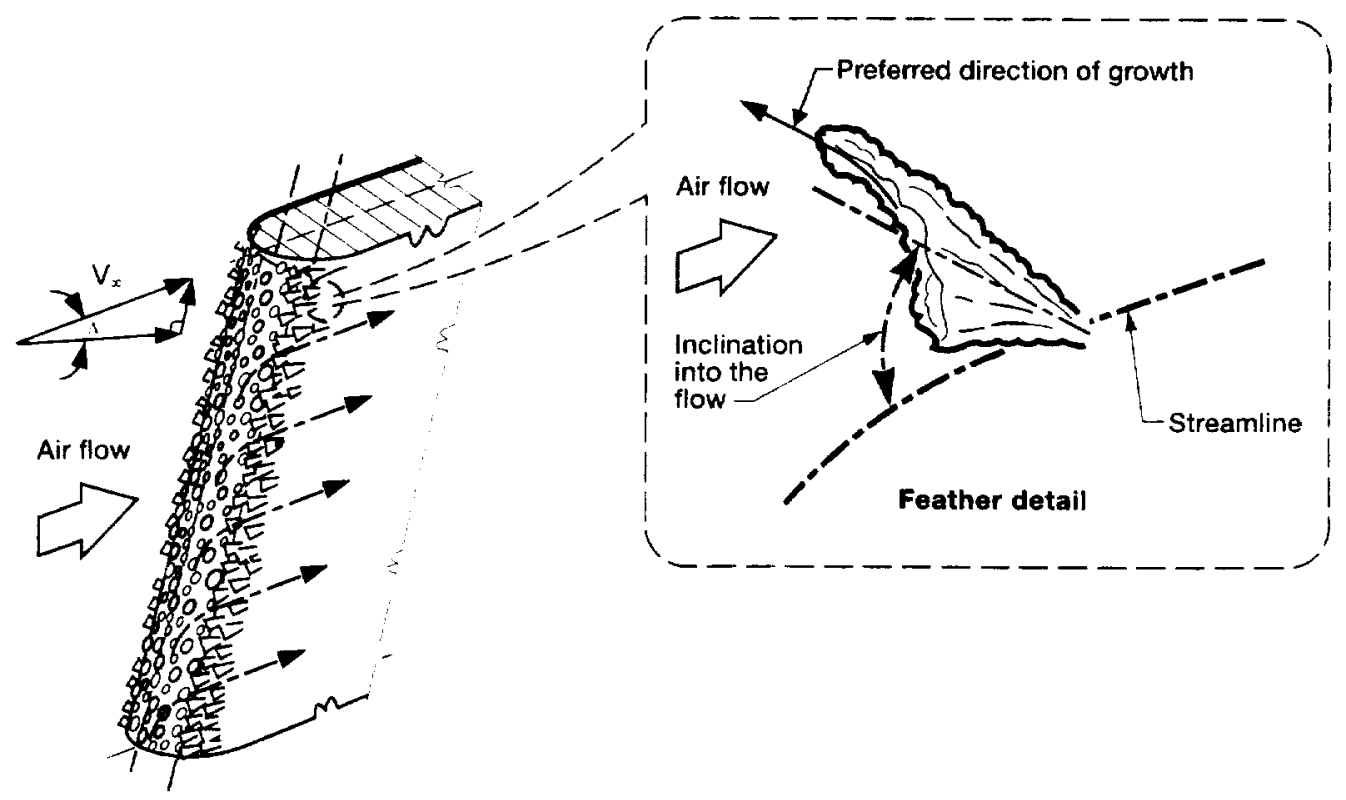

Figure 2. Glaze ice feathers with preferred direction of growth perpendicular to external streamline. Note that feathers have a tooth shape and are inclined into the flow

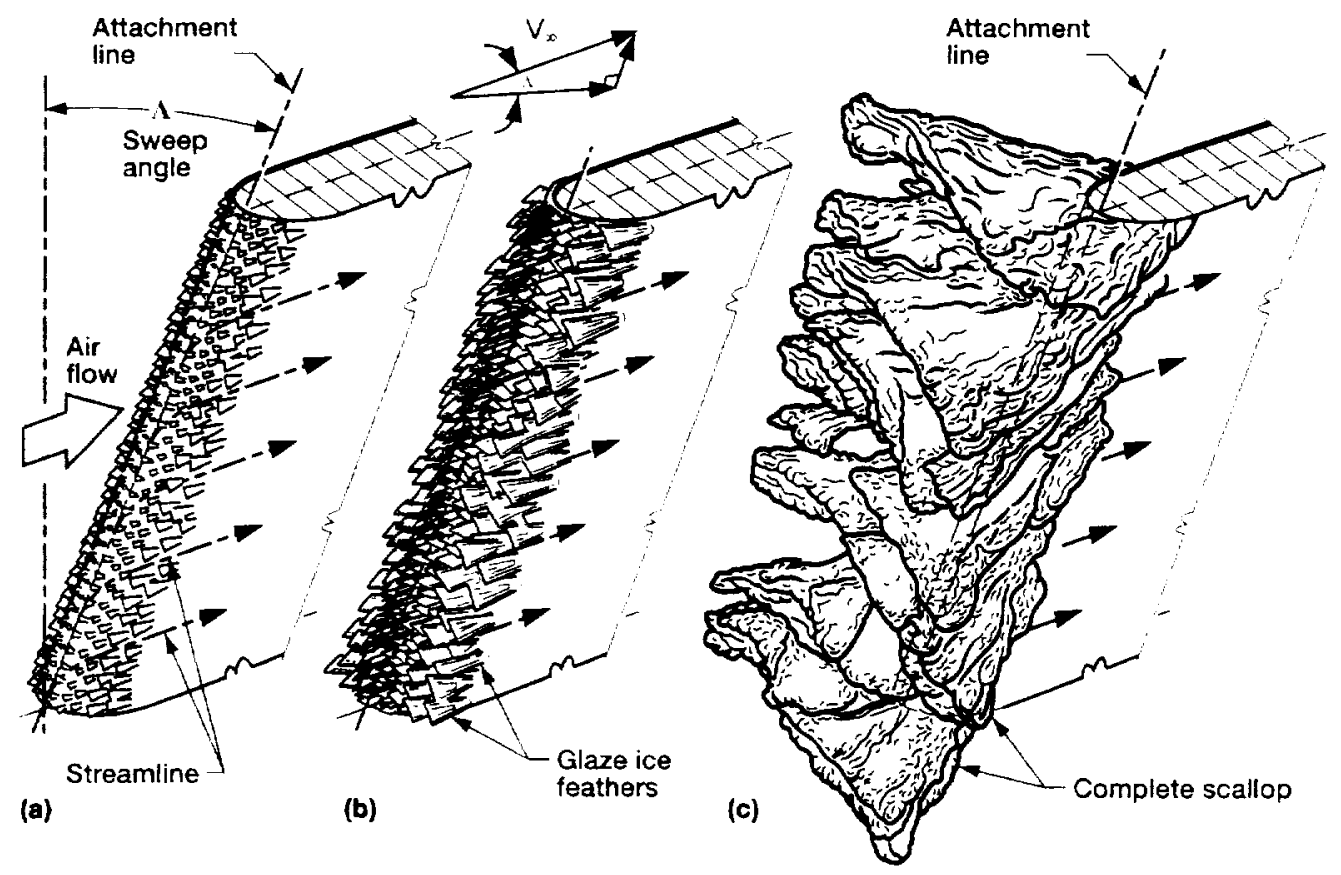

Figure 3. Ice accretion on a swept wing at glaze ice conditions, complete scallop case, critical distance $=0$. (a) Roughness elements (all over the ice accretion) develop into glaze ice feathers with a preferred direction of growth perpendicular to the external streamlines. (b) The feathers join along the preferred direction of growth to form ridges that will develop into incipient scallop tips. (c) Incipient scallop tips join at their tops to form complete scallops. 


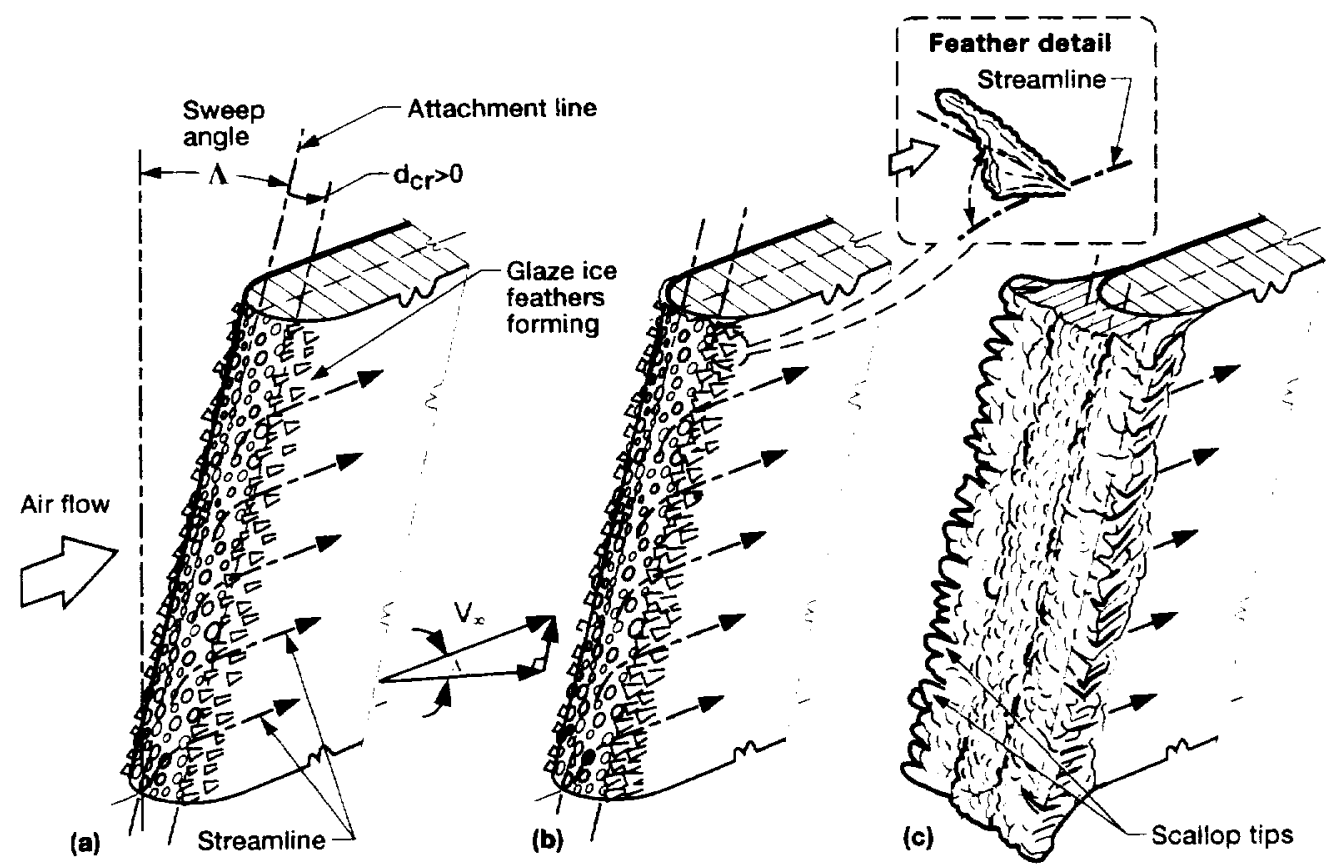

Figure 4. Ice accretion on a swept wing at glaze ice conditions, incomplete scallop case, critical distance $>0$.

(a) Well defined attachment line zone and glaze ice feathers zone. (b) The feathers' preferred direction of growth is aligned at a large enough angle with respect to the attachment line direction. The mechanisms of scallop tip formation can operate. (c) Scallop tips are formed starting at a given distance (the critical distance) from the attachment line proper.
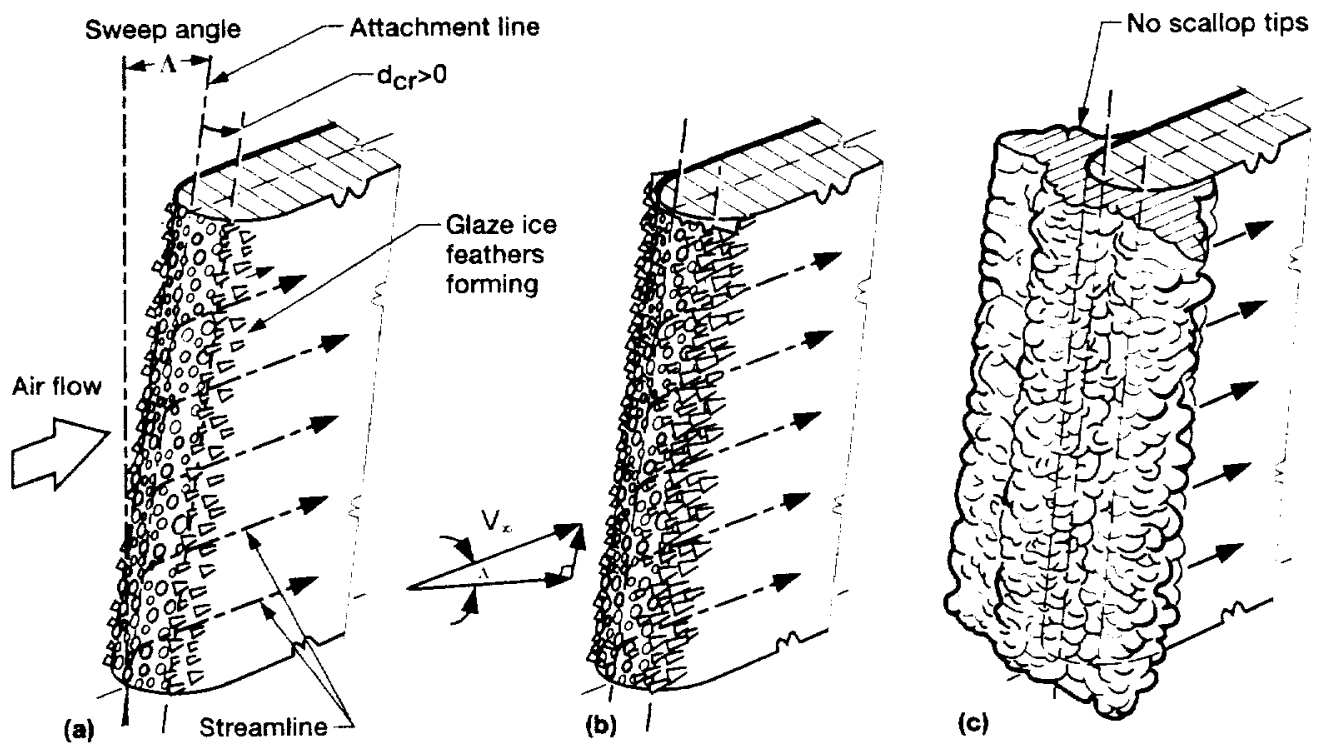

Figure 5. Ice accretion on a swept wing at glaze ice conditions, no-scallop case, critical distance $>0$. (a) Well defined attachment line zone and glaze ice feathers zone. (b) The feathers' preferred direction of growth is nearly parallel to the attachment line direction. This does not allow the mechanisms of scallop tip formation to operate. (c) Scallop tips are not formed. Attachment line ice eventually covers the feathers and spills on the side 


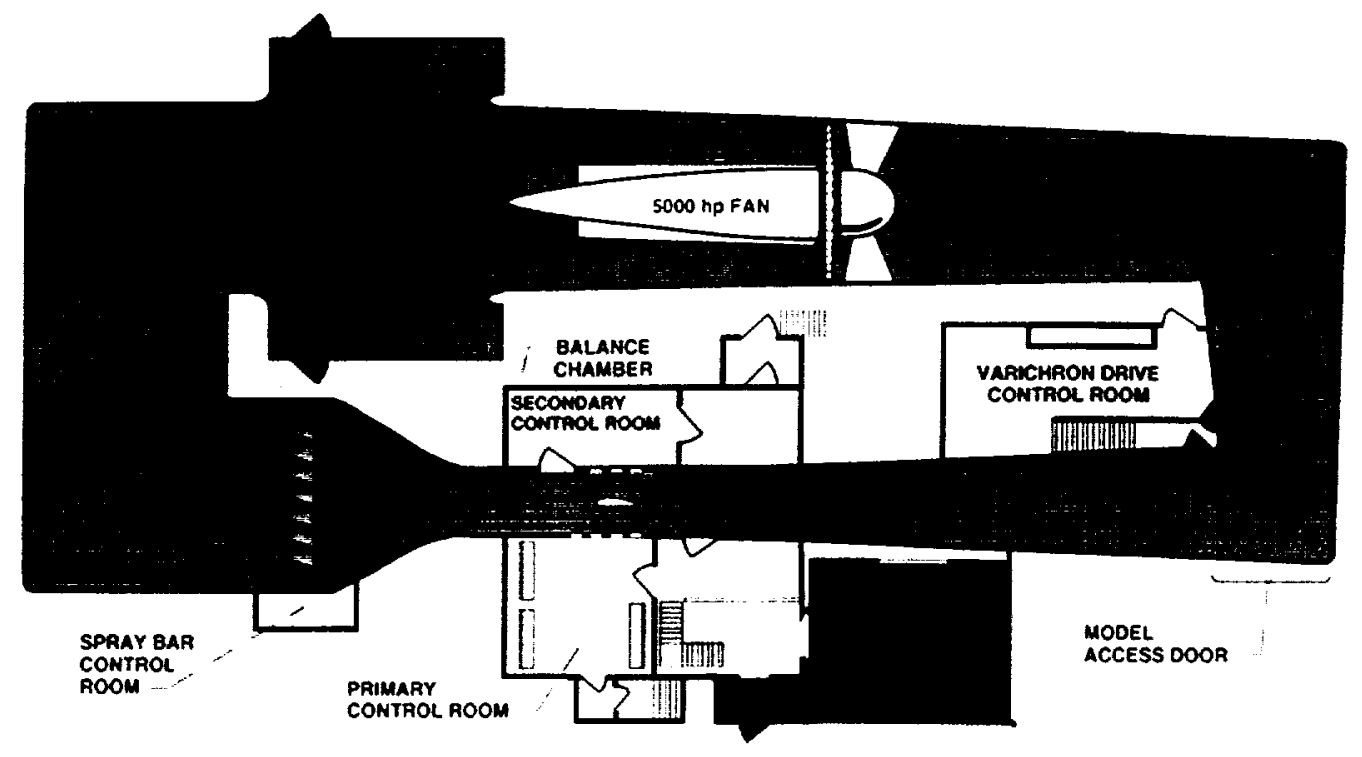

Figure 6. NASA Glenn Icing Research Tunnel, Plan view

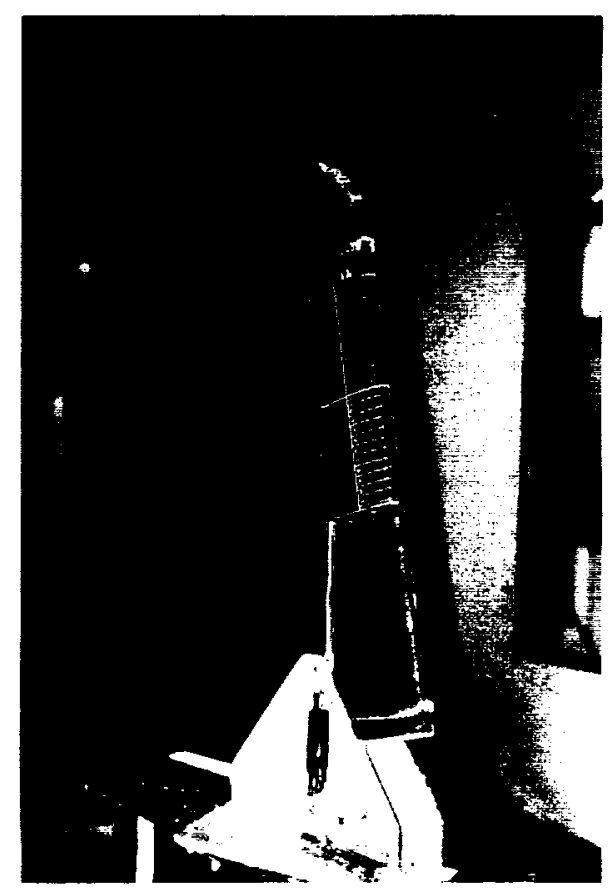

Figure 7. NACA 0012 swept wing tip in the IRT Test Section

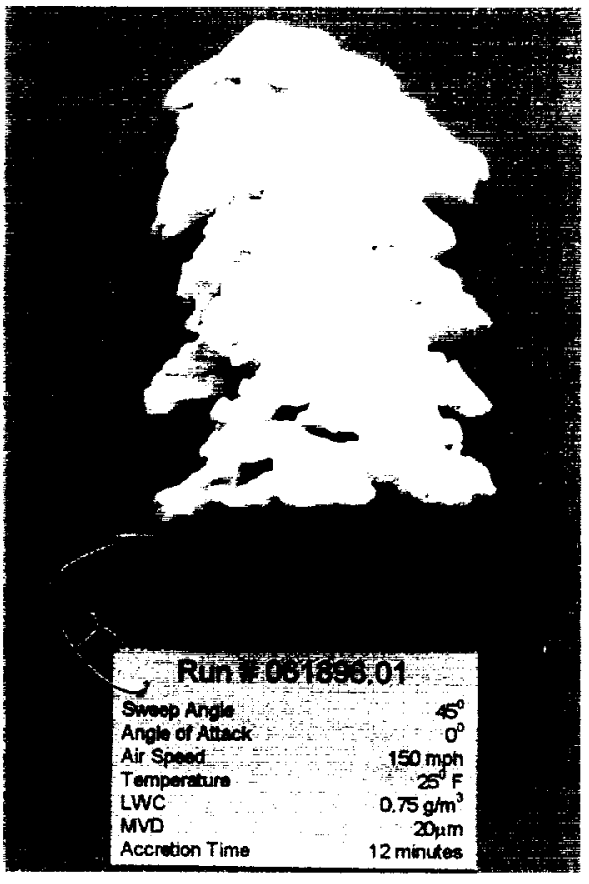

Figure 8. Urethane casting of an ice accretion 


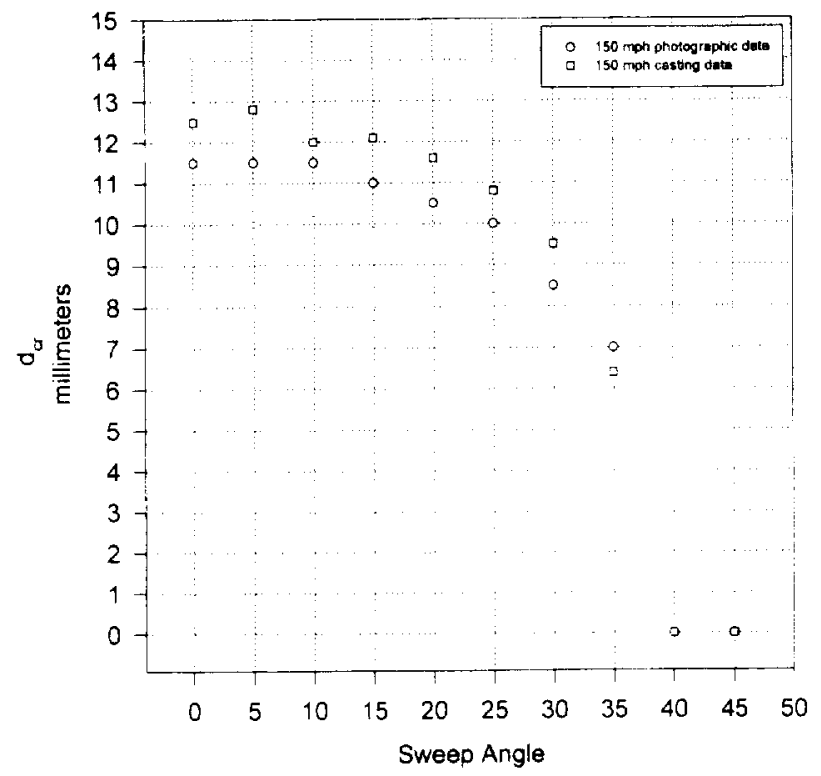

Figure 9. Change in critical distance with sweep angle at a velocity of $150 \mathrm{mph} . \mathrm{A}=0^{\circ}$ to $45^{\circ}$ at $5^{\circ}$ increments, $V=150 \mathrm{mph}, T=25^{\circ} \mathrm{F}$ $L W C=0.75 \mathrm{~g} / \mathrm{m}^{3}, M V D=20 \mu \mathrm{m}, \tau=5 \mathrm{~min}$.

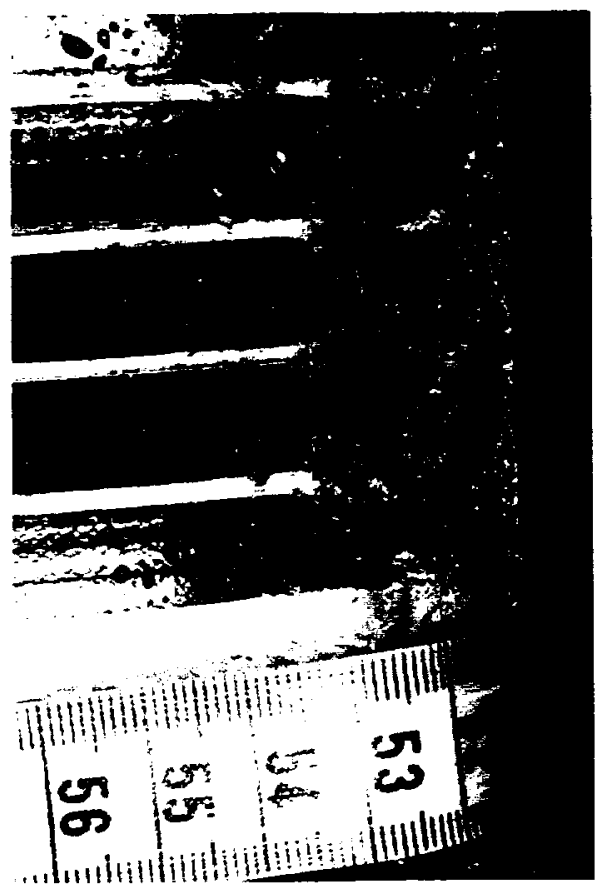

Figure 11. Side view of the ice accretion showing the ice of the attachment line zone covering the feathers in the glaze ice feathers zone. $\quad \Lambda=0^{\circ}, \quad V=150 \mathrm{mph}, \quad T=25^{\circ} \mathrm{F}$ $L W C=0.75 \mathrm{~g} / \mathrm{m}^{3}, M V D=20 \mu \mathrm{m}, \tau=5 \mathrm{~min}$. Scale of ruler is in centimeters, smallest division 1 millimeter

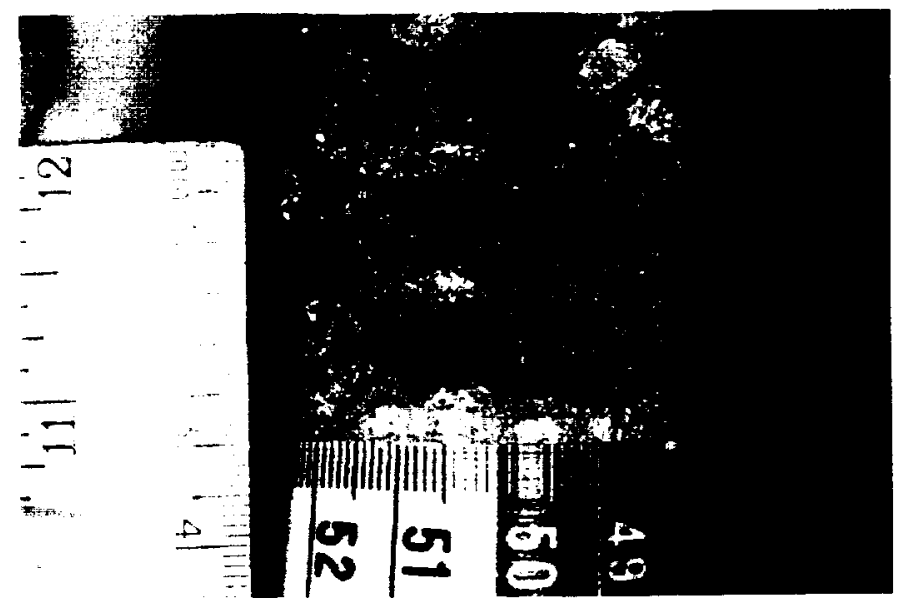

Figure 10. Front view of ice accretion showing the attachment line zone and the glaze ice feathers zone. $\quad A=0^{\circ}, V=150 \mathrm{mph}, T=25^{\circ} \mathrm{F}$, $L W C=0.75 \mathrm{~g} / \mathrm{m}^{3}, M V D=20 \mu \mathrm{m}, \tau=5 \mathrm{~min}$. Scale of ruler is in centimeters, smallest division 1 millimeter.

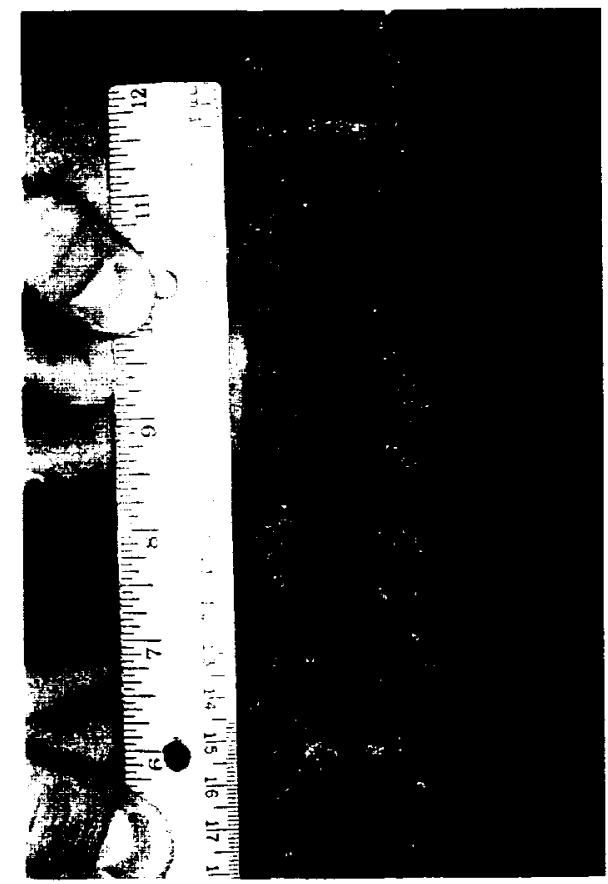

Figure 12. Front view of ice accretion showing the attachment line zone and the glaze ice feathers zone, with the feathers not forming scallop tips. $\Lambda=10^{\circ}, V=150 \mathrm{mph}, T=25^{\circ} \mathrm{F}$, $L W C=0.75 \mathrm{~g} / \mathrm{m}^{3}, \quad M V D=20 \mu \mathrm{m}, \quad \tau=5 \mathrm{~min}$. Direction of flow is from bottom to top, scale of ruler is in centimeters, smallest division 1 millimeter. 


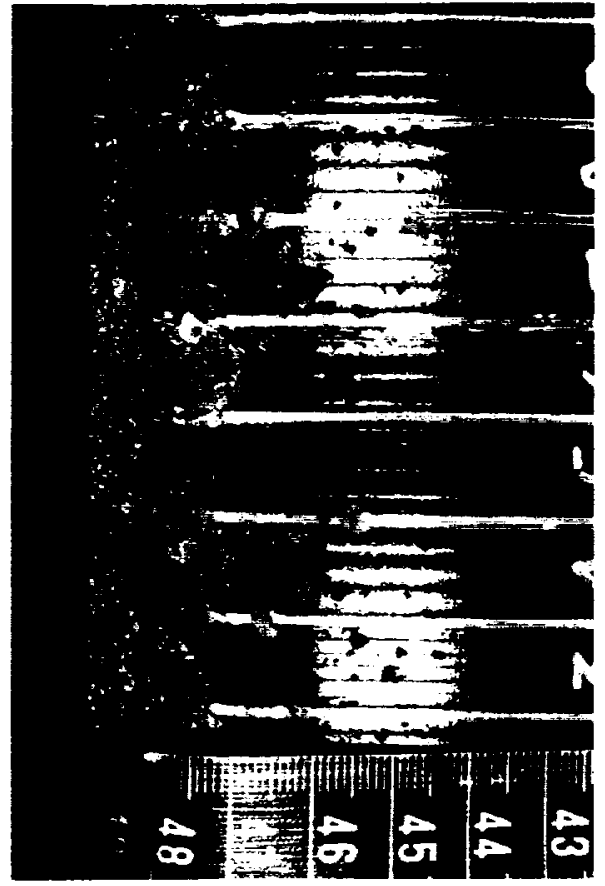

Figure 13. Side view of ice accretion showing the ice of the attachment line zone covering the feathers. $A=10^{\circ}, V=150 \mathrm{mph}, T=25^{\circ} \mathrm{F}$ $L W C=0.75 \mathrm{~g} / \mathrm{m}^{3}, \quad M V D=20 \mu \mathrm{m}, \quad \tau=5 \mathrm{~min}$. Direction of flow is from bottom to top, scale of ruler is in centimeters. smallest division 1 millimeter

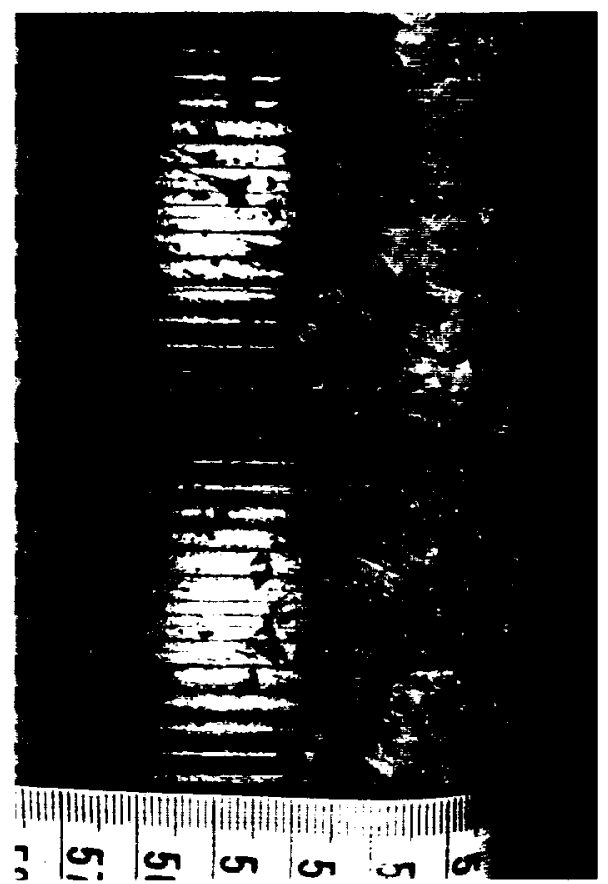

Figure 15. Side view of the ice accretion showing the feathers in the glaze ice feathers zone forming scallop tips. $\Lambda=25^{\circ}, V=150 \mathrm{mph}$ $T=25^{\circ} \mathrm{F}, L W C=0.75 \mathrm{~g} / \mathrm{m}^{3}, M V D=20 \mu \mathrm{m}, \tau=5 \mathrm{~min}$ Direction of flow is from bottom to top. upper scale of ruler is in centimeters, smallest division 1 millimeter.

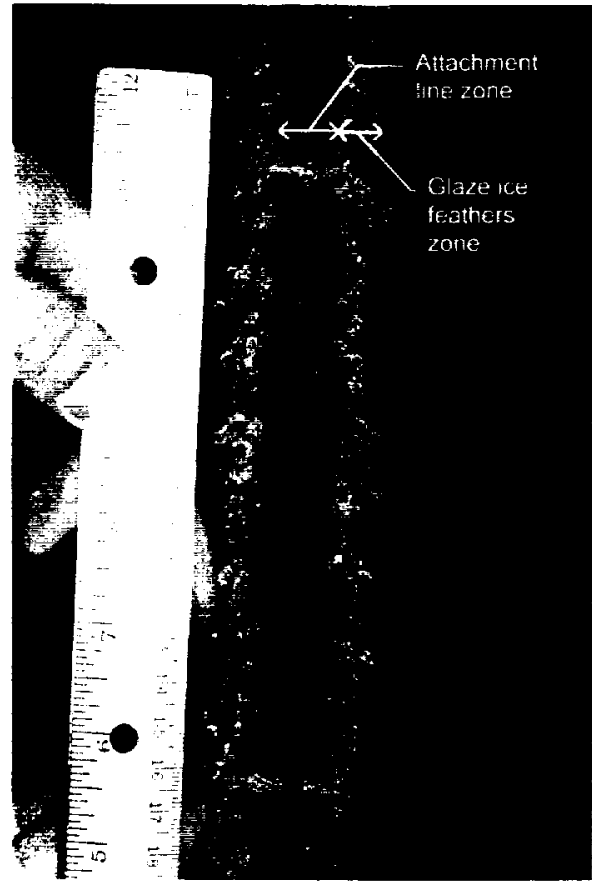

Figure 14. Front view of ice accretion showing the formation of scallop tips. $A=25^{\circ}, V=150$ $\mathrm{mph}, \quad \mathrm{T}=25^{\circ} \mathrm{F}, \quad L W C=0.75 \mathrm{~g} / \mathrm{m}^{3}, \quad M V D=20 \mu \mathrm{m}$ $\tau=5 \mathrm{~min}$. Direction of flow is from bottom to top scale of ruler is in centimeters, smallest division 1 millimeter.

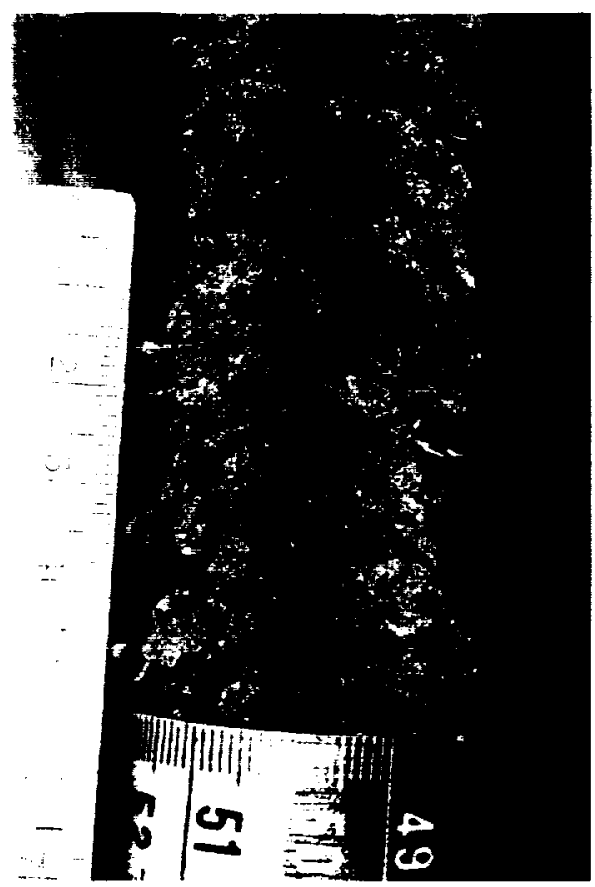

Figure 16. Front view of ice accretion showing scallop tips and the attachment line zone $\Lambda=35^{\circ}, V=150 \mathrm{mph}, T=25^{\circ} \mathrm{F}, L W C=0.75 \mathrm{~g} / \mathrm{m}^{3}$ MVD $=20 \mu \mathrm{m}, \tau=5 \mathrm{~min}$. Direction of flow is from bottom to top, scale of ruler is in centimeters. smallest division 1 millimeter. 


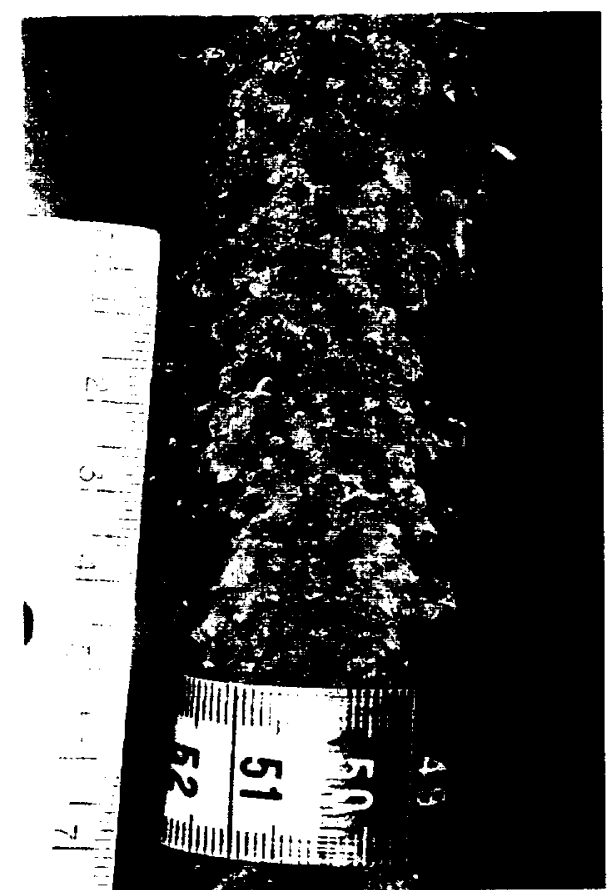

Figure 17. Complete scallop at $\Lambda=40^{\circ}, V=150$ $\mathrm{mph}, T=25^{\circ} \mathrm{F}, \quad L W C=0.75 \mathrm{~g} / \mathrm{m}^{3}, \quad M V D=20 \mu \mathrm{m}$, $\tau=5 \mathrm{~min}$. Direction of flow is from bottom to top, scale of ruler is in centimeters, smallest division 1 millimeter.

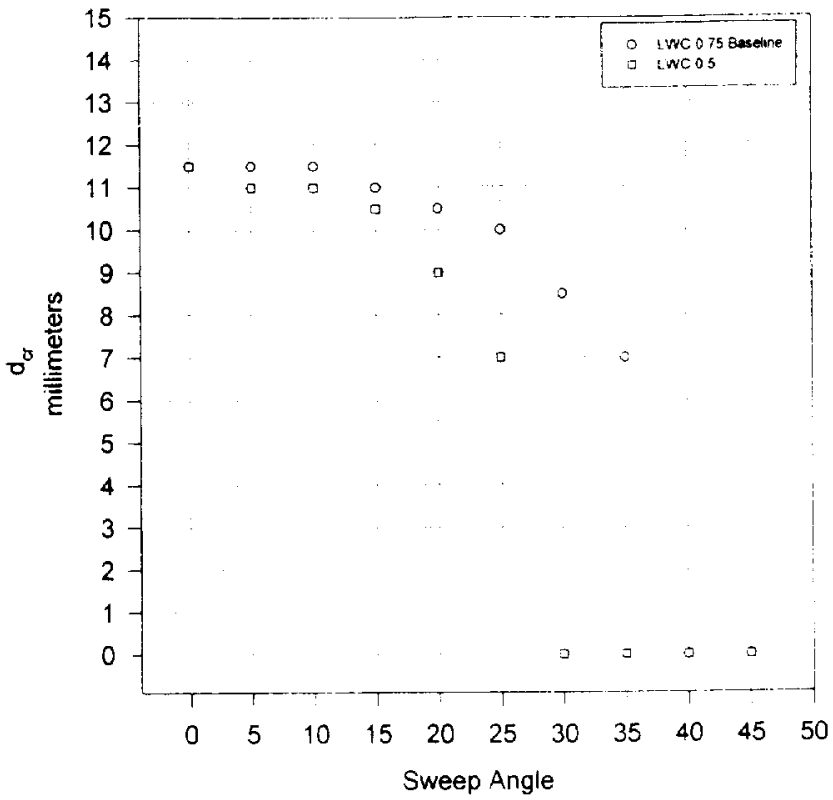

Figure 18. Change in critical distance with sweep angle for LWCs of $0.75 \mathrm{~g} / \mathrm{m}^{3}$ and 0.5 $\mathrm{g} / \mathrm{m}^{3} . \Lambda=0^{\circ}$ to $45^{\circ}$ at $5^{\circ}$ increments, $V=150$ $\mathrm{mph}, T=25^{\circ} \mathrm{F}, M V D=20 \mu \mathrm{m}, \tau=5 \mathrm{~min}$.

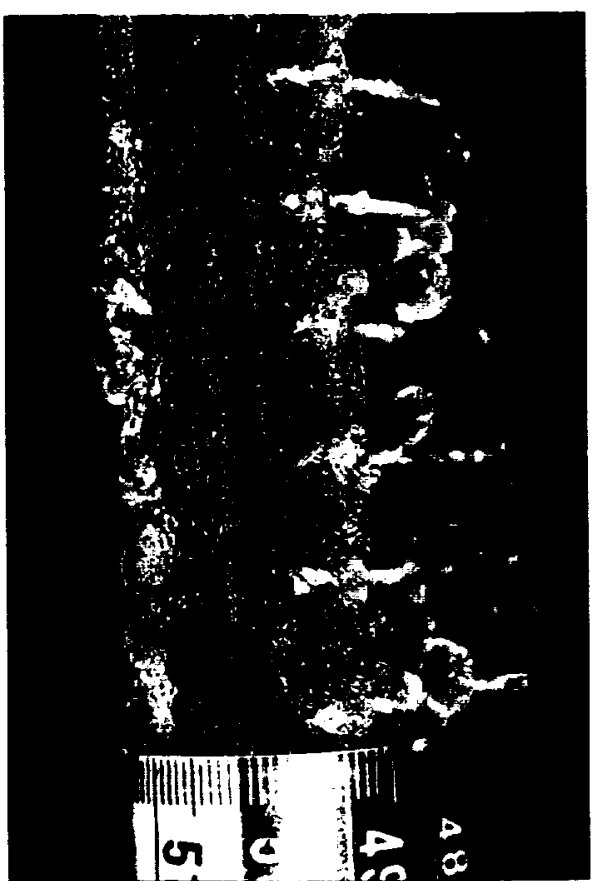

Figure 20. Side view of ice accretion showing the attachment line ice covering the tops of the feathers in the glaze ice feathers zone. $\Lambda=0^{\circ}$, $V=150 \quad \mathrm{mph}, \quad T=25^{\circ} \mathrm{F}, \quad L W C=0.5 \mathrm{~g} / \mathrm{m}^{3}$, $M V D=20 \mu \mathrm{m}, \tau=5 \mathrm{~min}$. Direction of flow is from bottom to top, scale of ruler is in centimeters, smallest division 1 millimeter. 


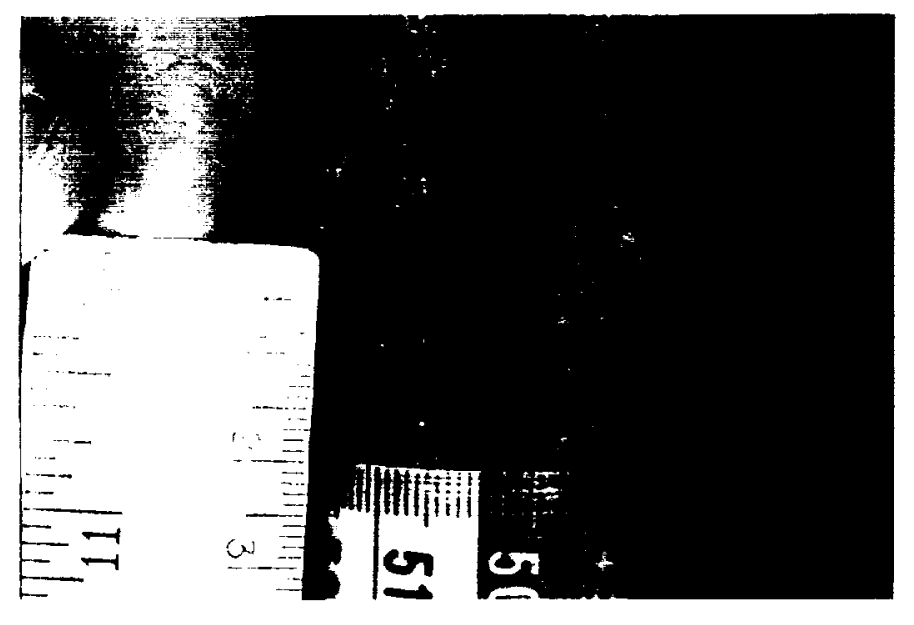

Figure 21. Front view of ice accretion at $\Lambda=20^{\circ}, V=150 \mathrm{mph}, T=25^{\circ} \mathrm{F}, \quad L W C=0.5 \mathrm{~g} / \mathrm{m}^{3}$, $M V D=20 \mu \mathrm{m}, r=5 \mathrm{~min}$. Direction of flow is from bottom to top. scale of ruler is in centimeters, smallest division 1 millimeter.

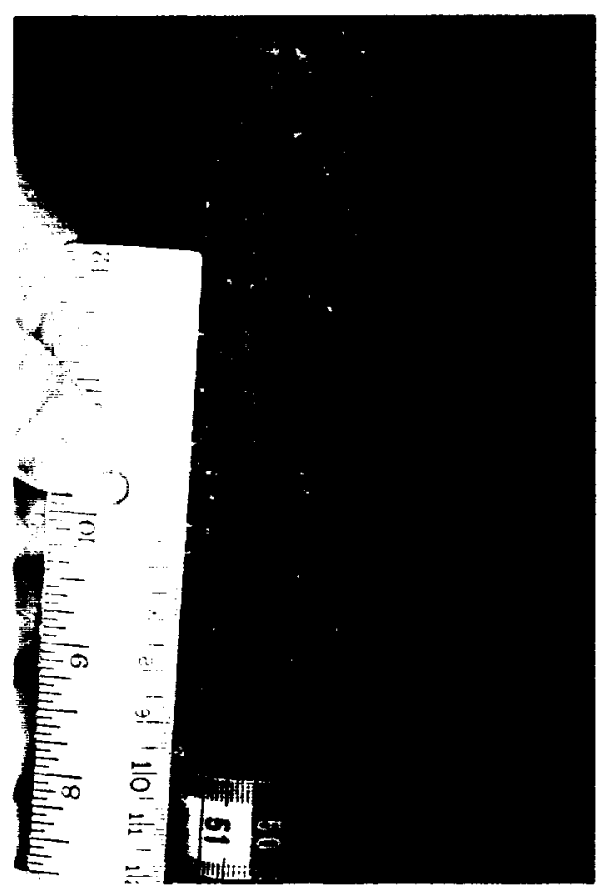

Figure 23. Front view of ice accretion at $\Lambda=25^{\circ}, V=150 \mathrm{mph}, T=25^{\circ} \mathrm{F}, \quad L W C=0.5 \mathrm{~g} / \mathrm{m}^{3}$, $M V D=20 \mu \mathrm{m}, \tau=5 \mathrm{~min}$. Direction of flow is from boltom to top, scale of ruler is in centimeters. smallest division 1 millimeter.

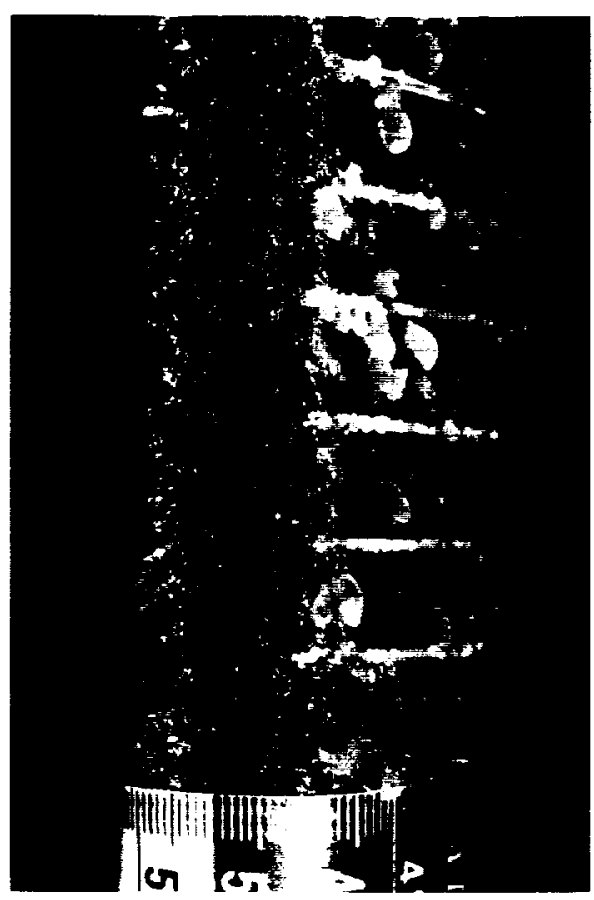

Figure 22. Side view of ice accretion at $\lambda=20^{\circ}$, $V=150 \quad \mathrm{mph}, \quad T=25^{\circ} \mathrm{F}, \quad L W C=0.5 \mathrm{~g} / \mathrm{m}^{3}$. $M V D=20 \mu \mathrm{m}, r=5 \mathrm{~min}$. Direction of flow is from bottom to top, scale of ruler is in centimeters. smallest division 1 millimeter.

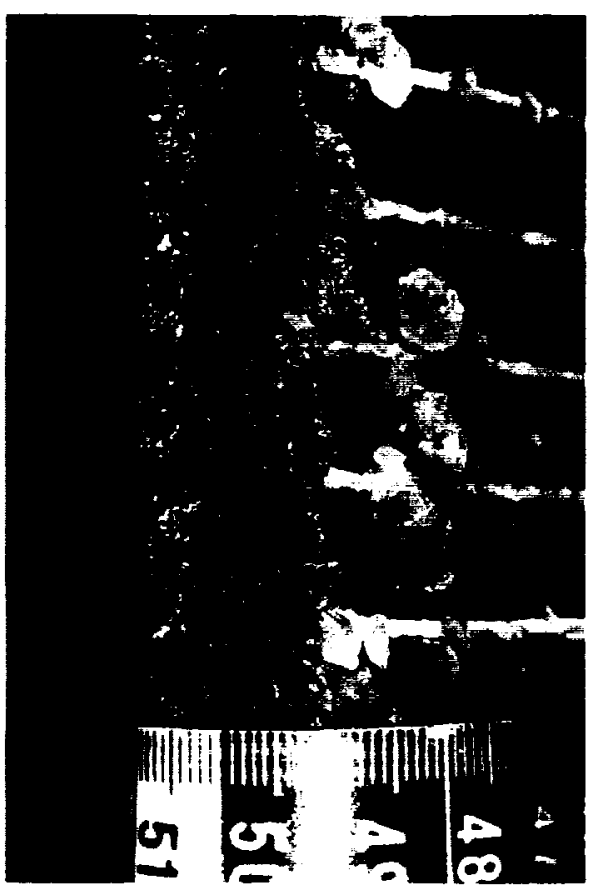

Figure 24. Side view of ice accretion at $\Lambda=25^{\circ}$, $V=150 \quad \mathrm{mph}, \quad T=25^{\circ} \mathrm{F}, \quad L W C=0.5 \mathrm{~g} / \mathrm{m}^{3}$, $M V D=20 \mu \mathrm{m}, \tau=5 \mathrm{~min}$. Direction of flow is from bottom to top, scale of ruler is in centimeters, smallest division 1 millimeter. 


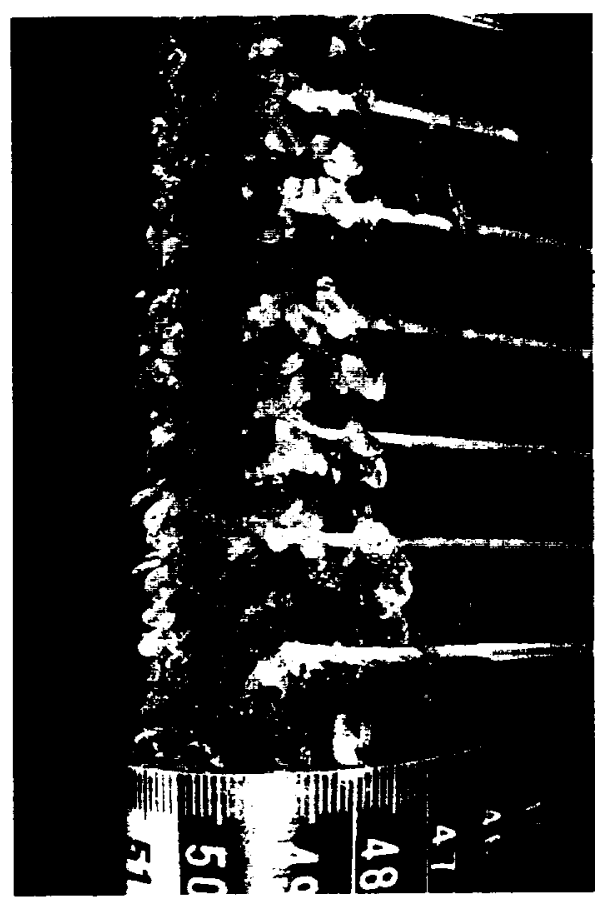

Figure 25. Side view of ice accretion at $\Lambda=30^{\circ}$ $V=150 \quad \mathrm{mph}, \quad T=25^{\circ} \mathrm{F}, \quad L W C=0.5 \mathrm{~g} / \mathrm{m}^{3}$, $M V D=20 \mu \mathrm{m}, \tau=5 \mathrm{~min}$. Direction of flow is from bottom to top, scale of ruler is in centimeters, smallest division 1 millimeter.

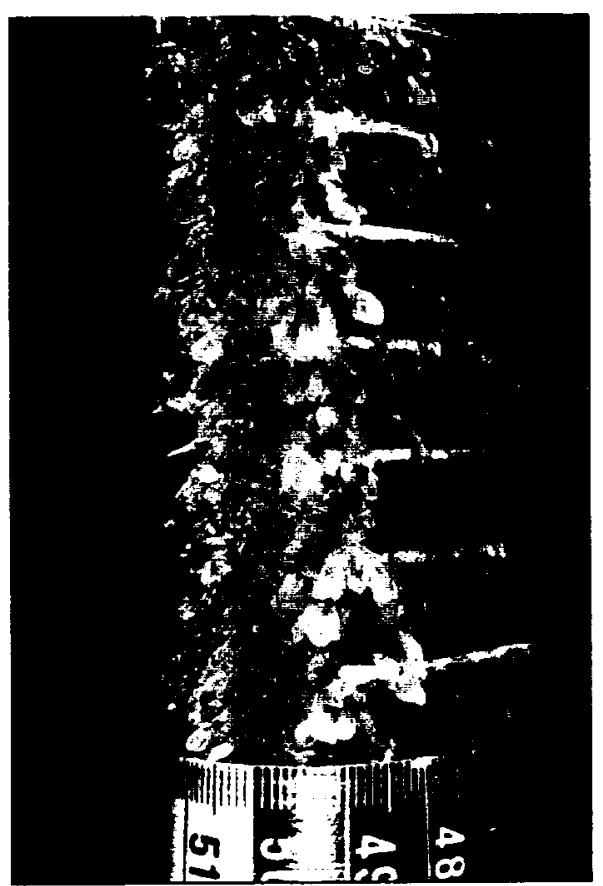

Figure 27. Side view of ice accretion at $\Lambda=35^{\circ}$ $V=150 \quad \mathrm{mph}, \quad T=25^{\circ} \mathrm{F}, \quad L W C=0.5 \mathrm{~g} / \mathrm{m}^{3}$, $M V D=20 \mu \mathrm{m}, \tau=5 \mathrm{~min}$. Direction of flow is from bottom to top, scale of ruler is in centimeters, smallest division 1 millimeter.

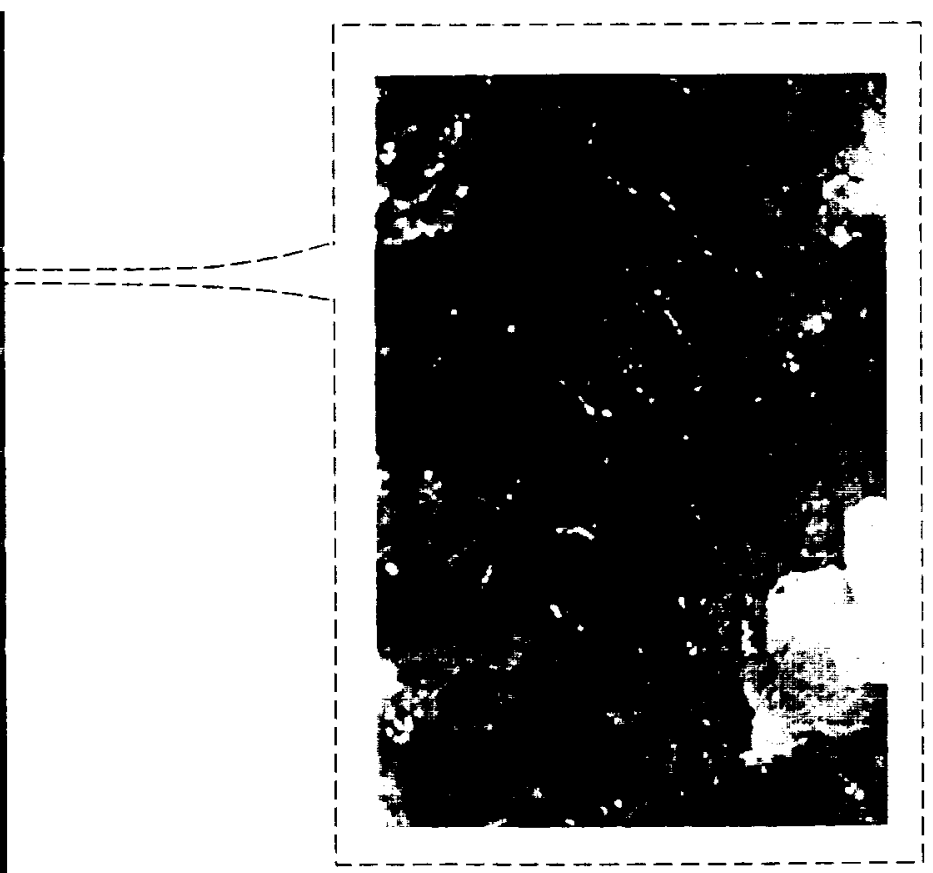

Figure 26. Enlargement of zone around the attachment line area of the ice accretion presented in figure 25 . Large feathers around the attachment line area can be observed Only the top of the feathers can be seen, the space between them is filled with ice.

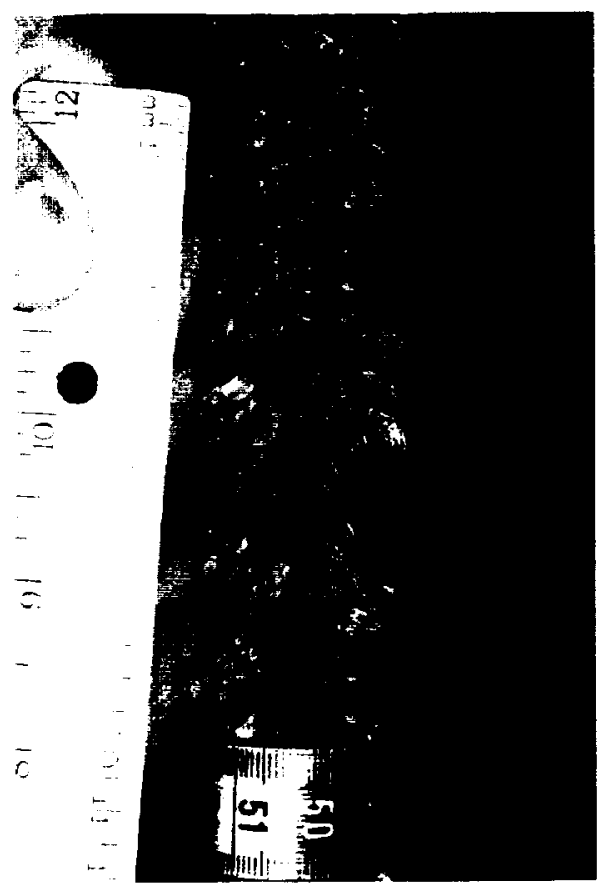

Figure 28. Front view of ice accretion at $\Lambda=45^{\circ}, V=150 \mathrm{mph}, T=25^{\circ} \mathrm{F}, L W C=0.5 \mathrm{~g} / \mathrm{m}^{3}$, $M V D=20 \mu \mathrm{m}, \tau=5 \mathrm{~min}$. Direction of flow is from bottom to top, scale of ruler is in centimeters, smallest division 1 millimeter 


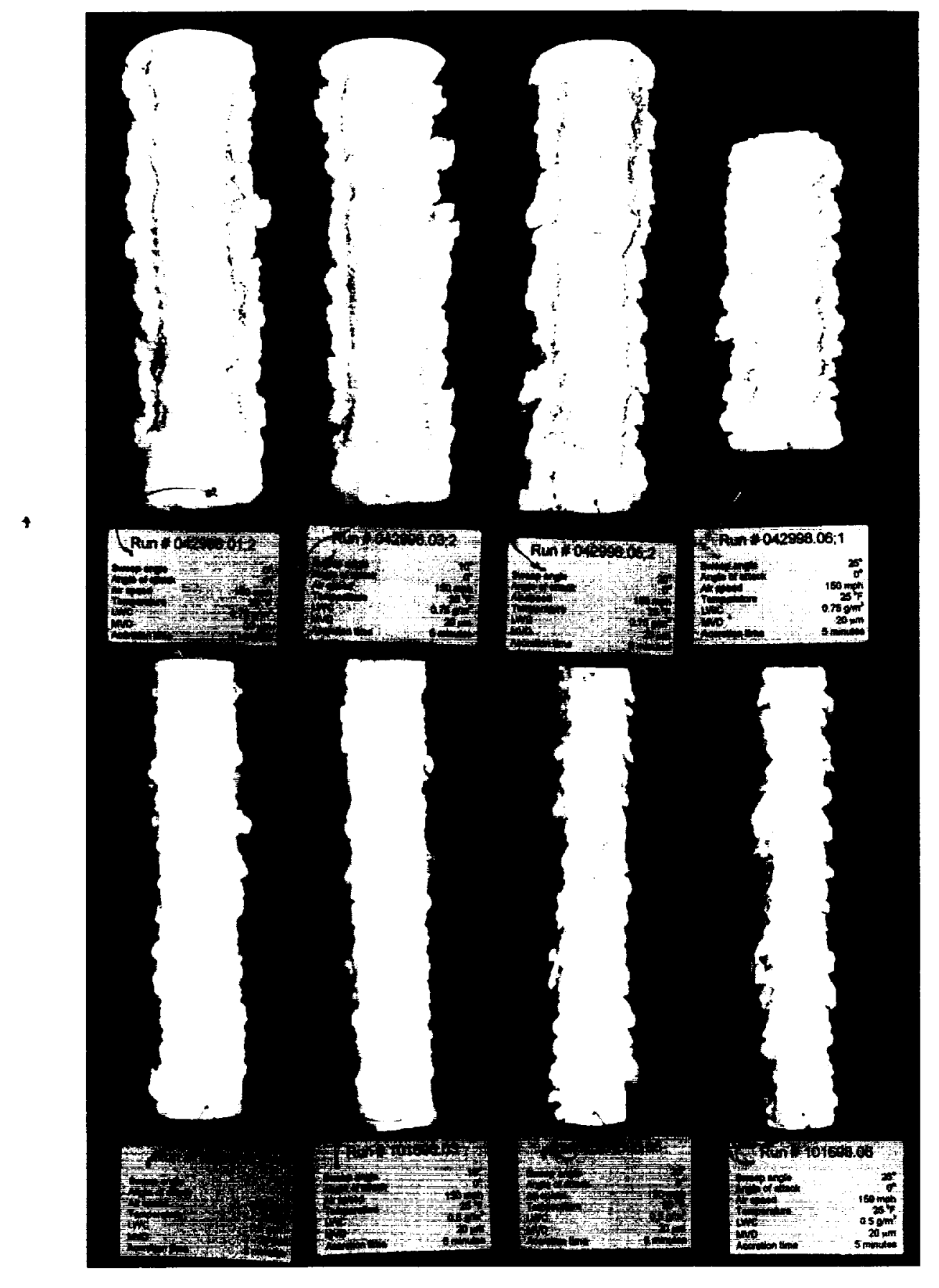

Figure 29. Casting data at sweep angles of $0^{\circ}, 10^{\circ}, 20^{\circ}$, and $25^{\circ}$, for $L W C s$ of $0.75 \mathrm{~g} / \mathrm{m}^{3}$ (upper castings) and $0.5 \mathrm{~g} / \mathrm{m}^{3}$ (lower castings). $V=150 \mathrm{mph}, T=25^{\circ} \mathrm{F}, M V D=20 \mu \mathrm{m}, \tau=5 \mathrm{~min}$. 


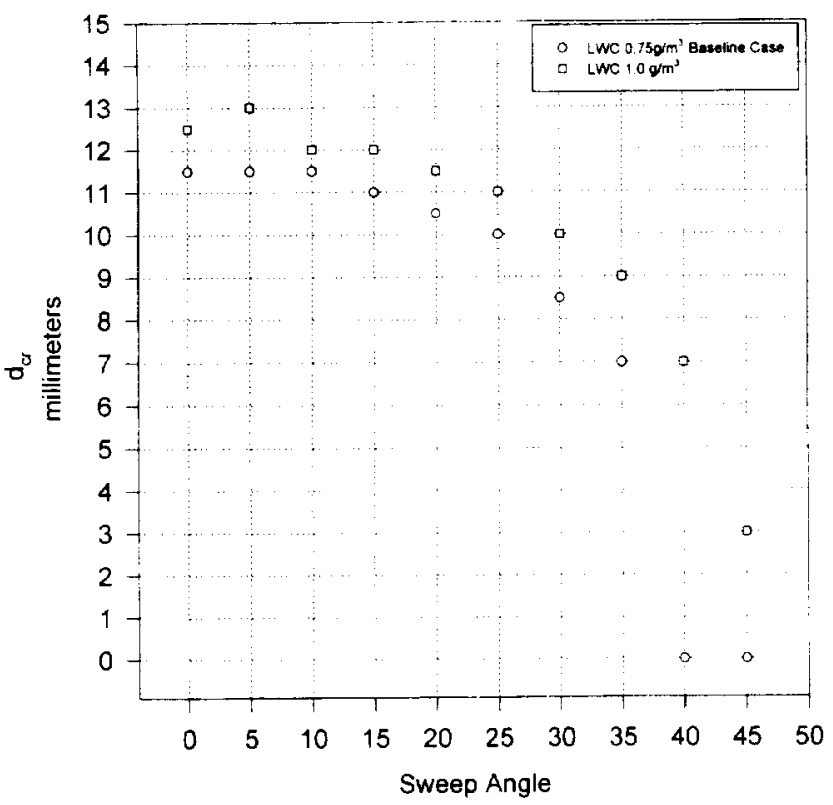

Figure 30. Change in critical distance with sweep angle at LWCs of $0.75 \mathrm{~g} / \mathrm{m}^{3}$ and $1.0 \mathrm{~g} / \mathrm{m}^{3} . \Lambda=0^{\circ}$ to $45^{\circ}$ at $5^{\circ}$ increments, $V=150$ $\mathrm{mph}, \mathrm{T}=25^{\circ} \mathrm{F}, \mathrm{MVD}=20 \mu \mathrm{m}, \tau=5 \mathrm{~min}$.

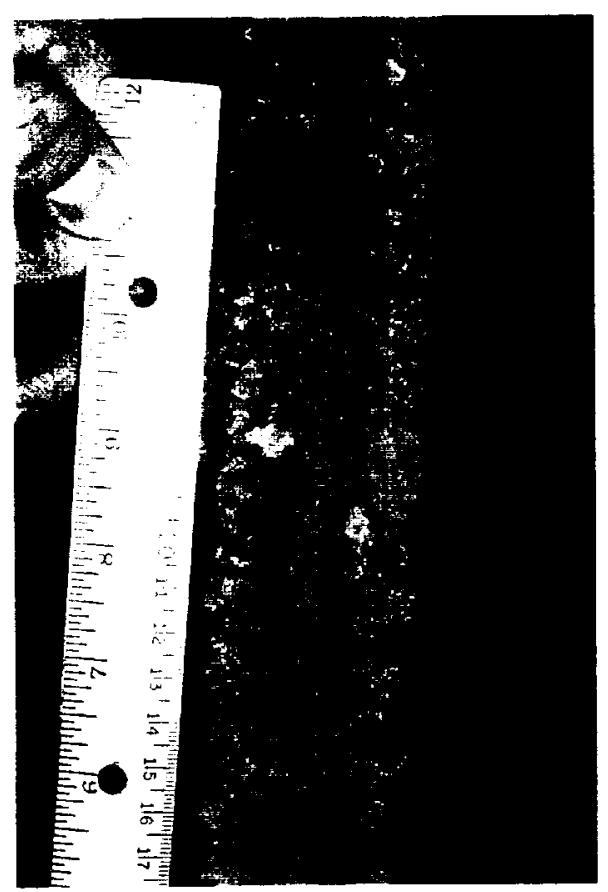

Figure 32. Front view of ice accretion at $\Lambda=15^{\circ}, V=150 \mathrm{mph}, \quad T=25^{\circ} \mathrm{F}, \quad L W C=1.0 \mathrm{~g} / \mathrm{m}^{3}$, $M V D=20 \mu \mathrm{m}, \tau=5 \mathrm{~min}$. Direction of flow is from bottom to top, scale of ruler is in centimeters. smallest division 1 millimeter

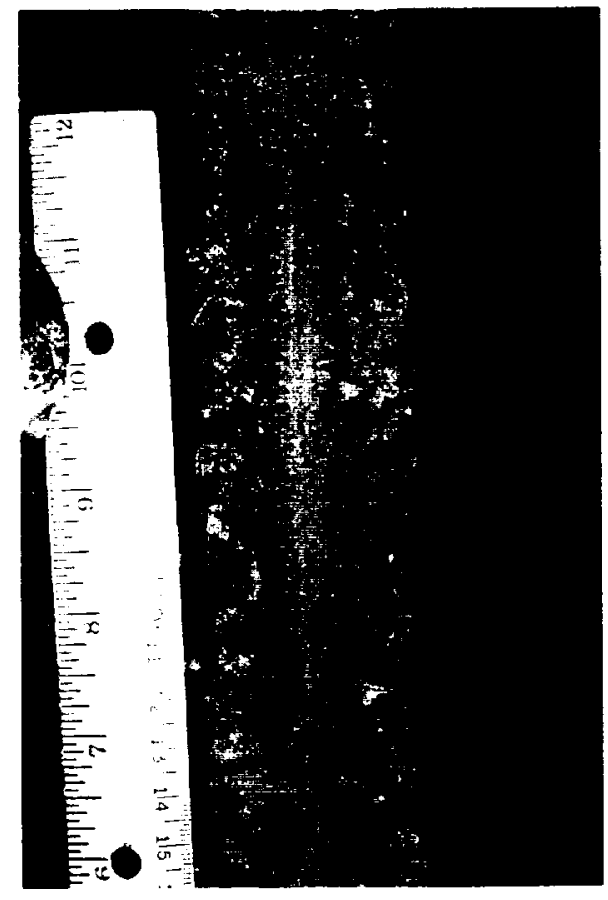

Figure 31. Front view of ice accretion at $\Lambda=0^{\circ}$ $V=150 \quad \mathrm{mph}, \quad T=25^{\circ} \mathrm{F}, \quad L W C=1.0 \mathrm{~g} / \mathrm{m}^{3}$, $M V D=20 \mu m, \tau=5 \mathrm{~min}$. Direction of flow is from bottom to top, scale of ruler is in centimeters. smallest division 1 millimeter.

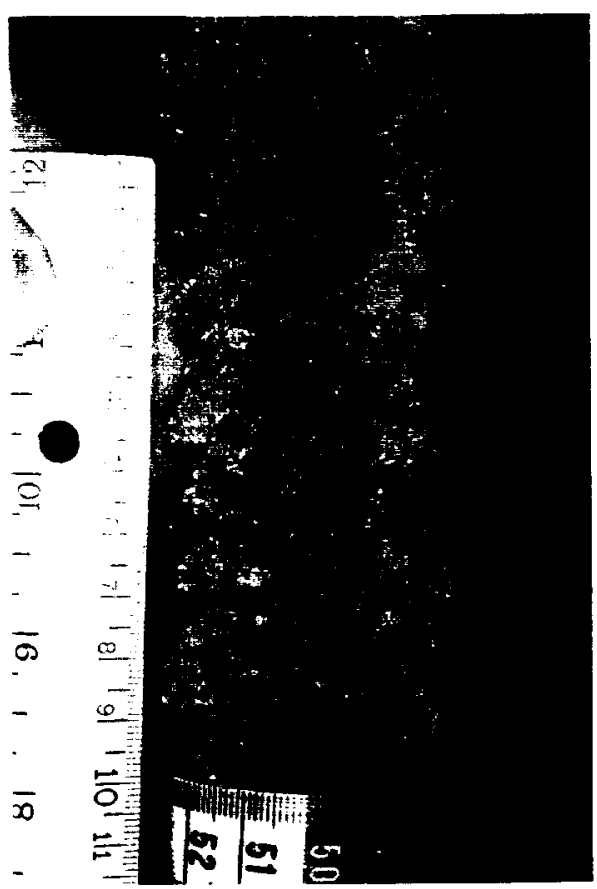

Figure 33. Front view of ice accretion at $\Lambda=30^{\circ}, V=150 \mathrm{mph}, T=25^{\circ} \mathrm{F}, \quad L W C=1.0 \mathrm{~g} / \mathrm{m}^{3}$, $M V D=20 \mu \mathrm{m}, \tau=5 \mathrm{~min}$. Direction of flow is from bottom to top, scale of ruler is in centimeters. smallest division 1 millimeter. 


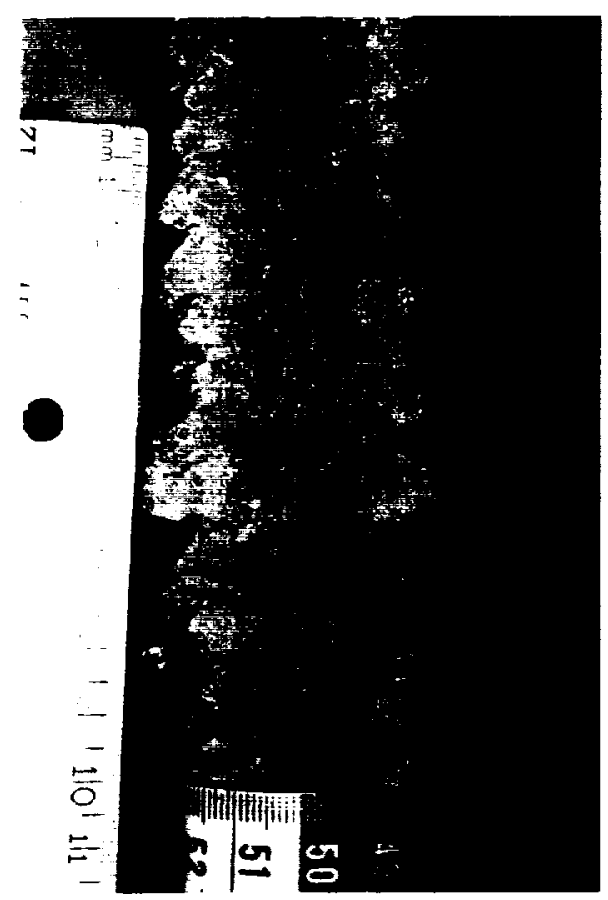

Figure 34. Front view of ice accretion at $\Lambda=35^{\circ}, V=150 \mathrm{mph}, T=25^{\circ} \mathrm{F}, \quad L W C=1.0 \mathrm{~g} / \mathrm{m}^{3}$, $M V D=20 \mu \mathrm{m}, \tau=5 \mathrm{~min}$. Direction of flow is from bottom to top, scale of ruler is in centimeters, smallest division 1 millimeter

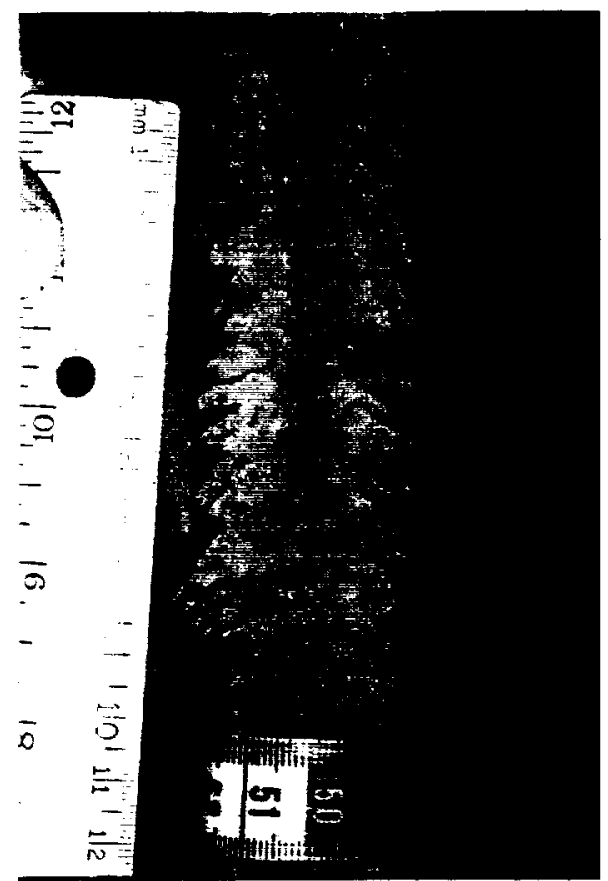

Figure 36. Front view of ice accretion at $\Lambda=45^{\circ}, V=150 \mathrm{mph}, T=25^{\circ} \mathrm{F}, \quad L W C=1.0 \mathrm{~g} / \mathrm{m}^{3}$, $M V D=20 \mu \mathrm{m}, \tau=5 \mathrm{~min}$. Direction of flow is from bottom to top, scale of ruler is in centimeters, smallest division 1 millimeter.

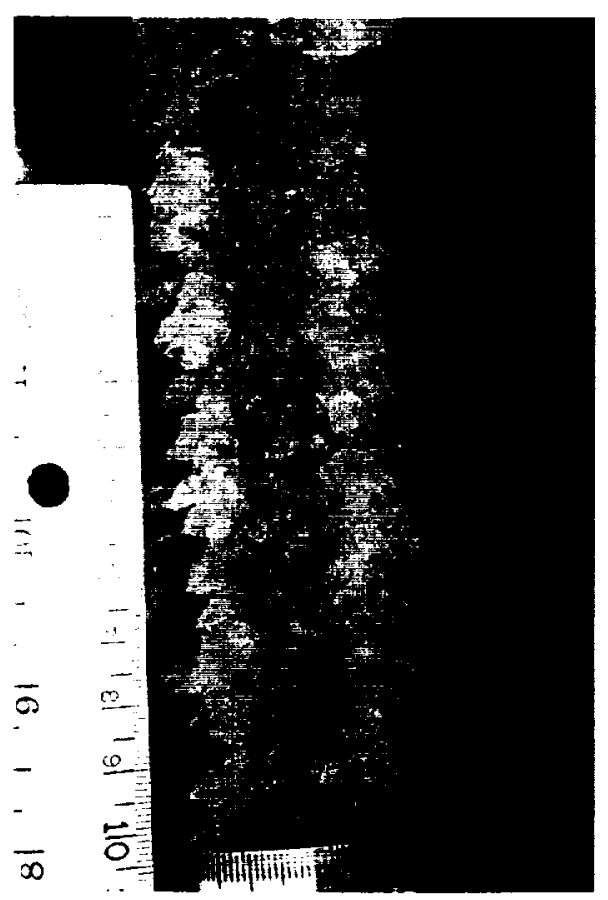

Figure 35. Front view of ice accretion at $\mathrm{A}=40^{\circ}, V=150 \mathrm{mph}, T=25^{\circ} \mathrm{F}, \quad L W C=1.0 \mathrm{~g} / \mathrm{m}^{3}$, $M V D=20 \mu \mathrm{m}, \tau=5 \mathrm{~min}$. Direction of flow is from bottom to top scale of ruler is in centimeters. smallest division 1 millimeter.

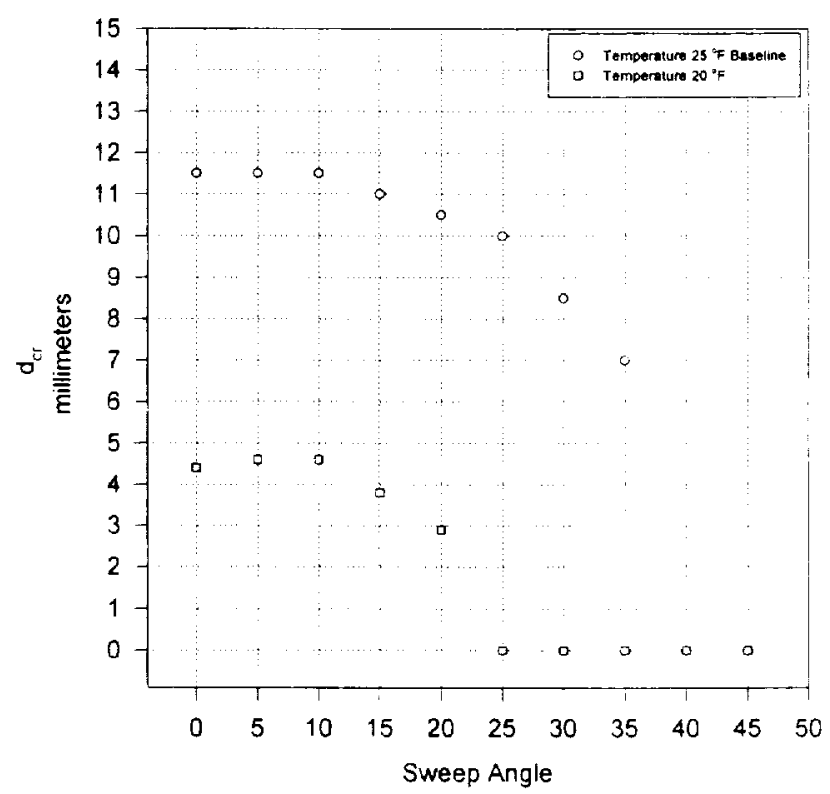

Figure 37. Change in critical distance with sweep angle at temperatures of $20^{\circ} \mathrm{F}$ and $25^{\circ} \mathrm{F}$ $\Lambda=0^{\circ}$ to $45^{\circ}$ at $5^{\circ}$ increments, $V=150 \mathrm{mph}$, $L W C=0.75 \mathrm{~g} / \mathrm{m}^{3}, M V D=20 \mu \mathrm{m}, \tau=5 \mathrm{~min}$. 


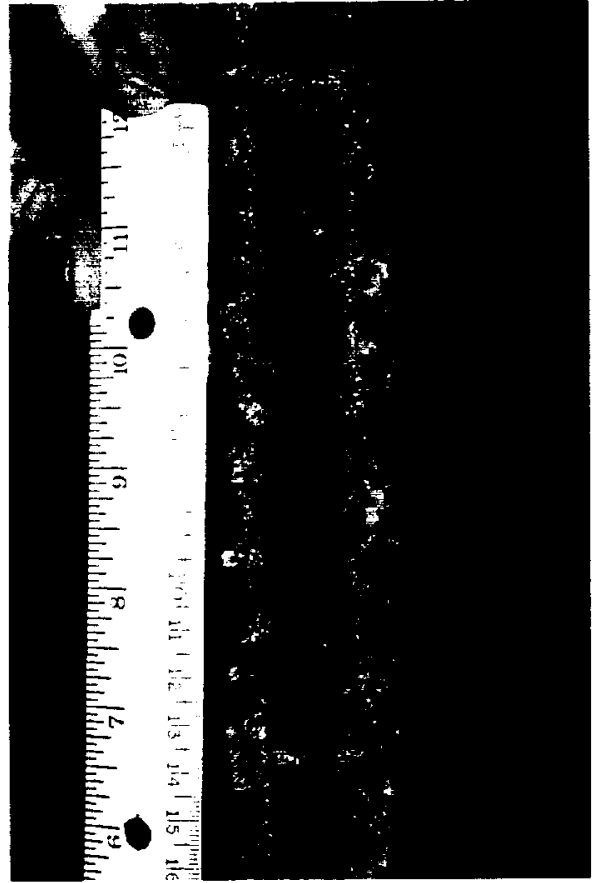

Figure 38. Front view of ice accretion at $\Lambda=0^{\circ}$ $V=150 \quad \mathrm{mph}, \quad T=20^{\circ} \mathrm{F}, \quad L W C=0.75 \mathrm{~g} / \mathrm{m}^{3}$. $M V D=20 \mu \mathrm{m}, \tau=5 \mathrm{~min}$. Direction of flow is from bottom to top, scale of ruler is in centimeters. smallest division 1 millimeter.

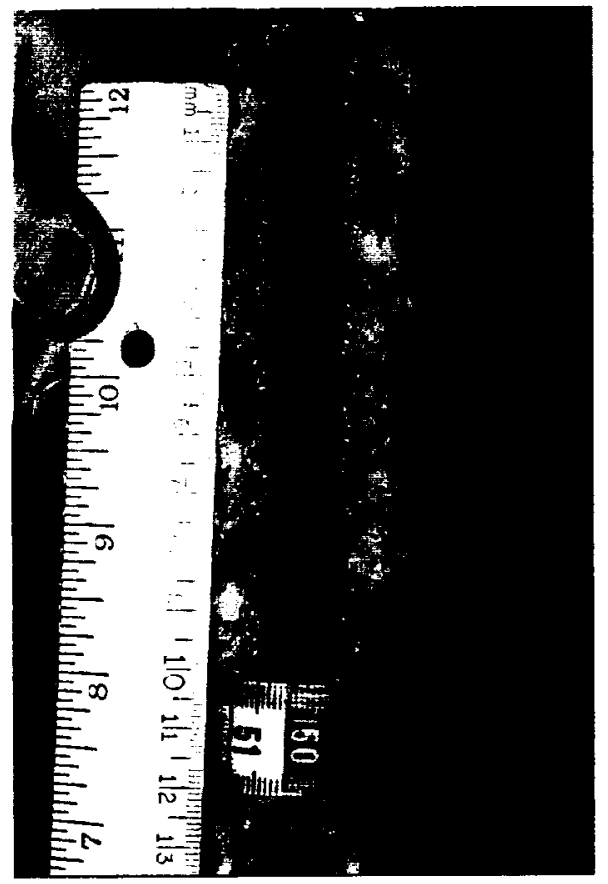

Figure 40. Front view of ice accretion at $\Lambda=20^{\circ}, V=150 \mathrm{mph}, T=20^{\circ} \mathrm{F}, L W C=0.75 \mathrm{~g} / \mathrm{m}^{3}$, $M V D=20 \mu \mathrm{m}, \tau=5 \mathrm{~min}$. Direction of flow is from bottom to top scale of ruler is in centimeters smallest division 1 millimeter.

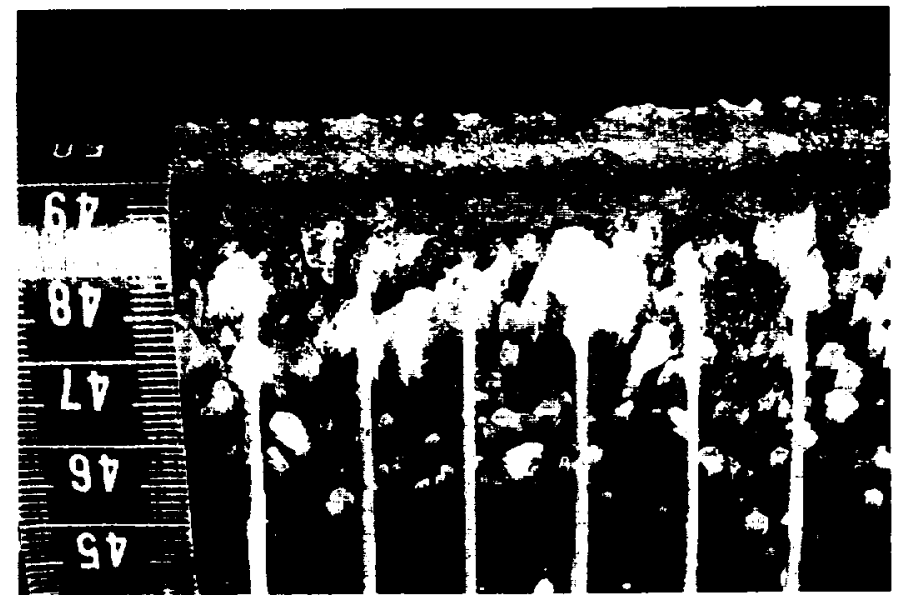

Figure 39. Side view of ice accretion at $\Lambda=0^{\circ}$ $V=150 \quad \mathrm{mph}, \quad T=20^{\circ} \mathrm{F}, \quad L W C=0.75 \mathrm{~g} / \mathrm{m}^{3}$ $M V D=20 \mu \mathrm{m}, \tau=5 \mathrm{~min}$. Direction of flow is from left to right, scale of ruler is in centimeters smallest division 1 millimeter.

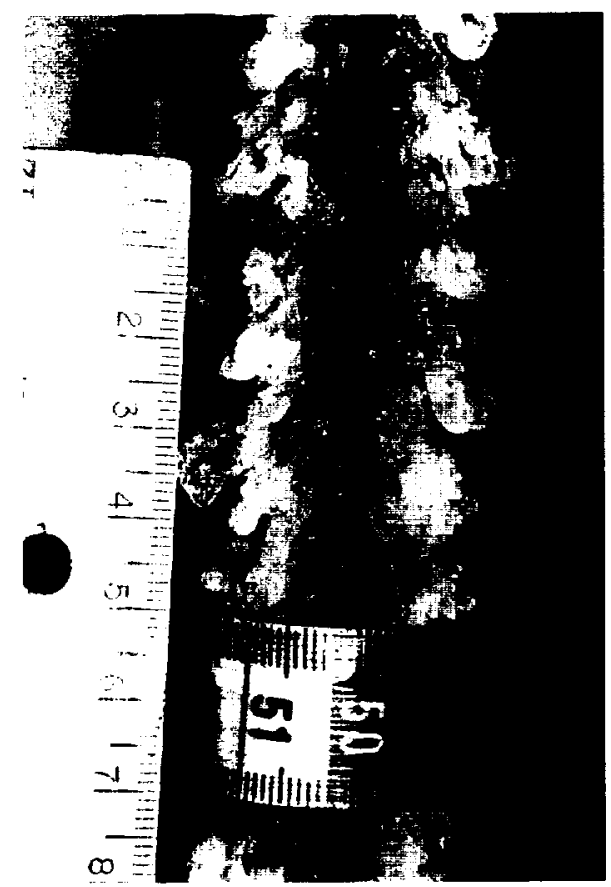

Figure 41. Front view of ice accretion at $\Lambda=25^{\circ}, V=150 \mathrm{mph}, T=20^{\circ} \mathrm{F}, L W C=0.75 \mathrm{~g} / \mathrm{m}^{3}$, $M V D=20 \mu \mathrm{m}, \tau=5 \mathrm{~min}$. Direction of flow is from bottom to top, scale of ruler is in centimeters smallest division 1 millimeter. 


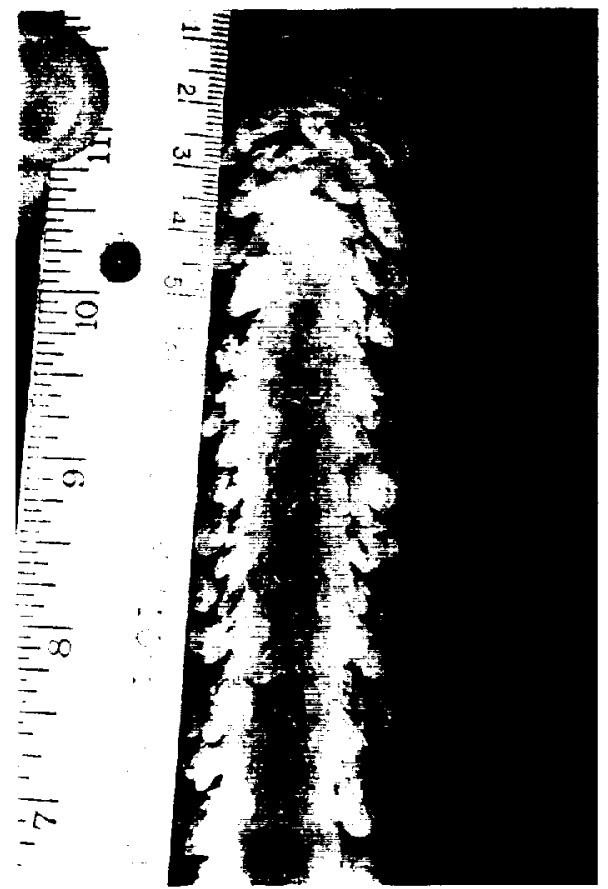

Figure 42. Front view of ice accretion just below the end cap. $\Lambda=25^{\circ}, V=150 \mathrm{mph}$, $T=20^{\circ} \mathrm{F}, L W C=0.75 \mathrm{~g} / \mathrm{m}^{3}, M V D=20 \mu \mathrm{m}, \tau=5 \mathrm{~min}$. Direction of flow is from bottom to top, scale of ruler is in centimeters, smallest division 1 millimeter.

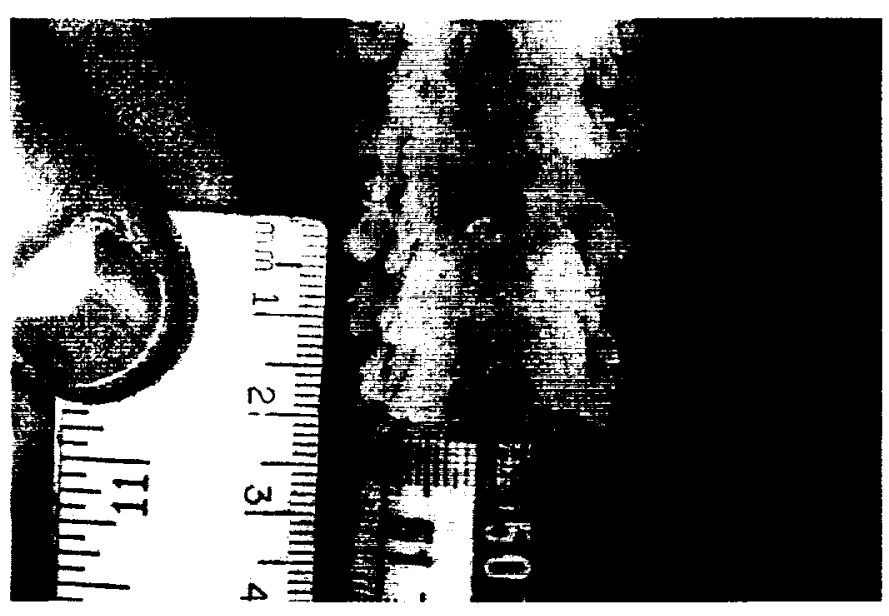

Figure 43. Front view of ice accretion at $\Lambda=30^{\circ}, V=150 \mathrm{mph}, T=20^{\circ} \mathrm{F}, L W C=0.75 \mathrm{~g} / \mathrm{m}^{3}$, $M V D=20 \mu \mathrm{m}, \tau=5 \mathrm{~min}$. Direction of flow is from bottom to top, scale of ruler is in centimeters smallest division 1 millimeter.
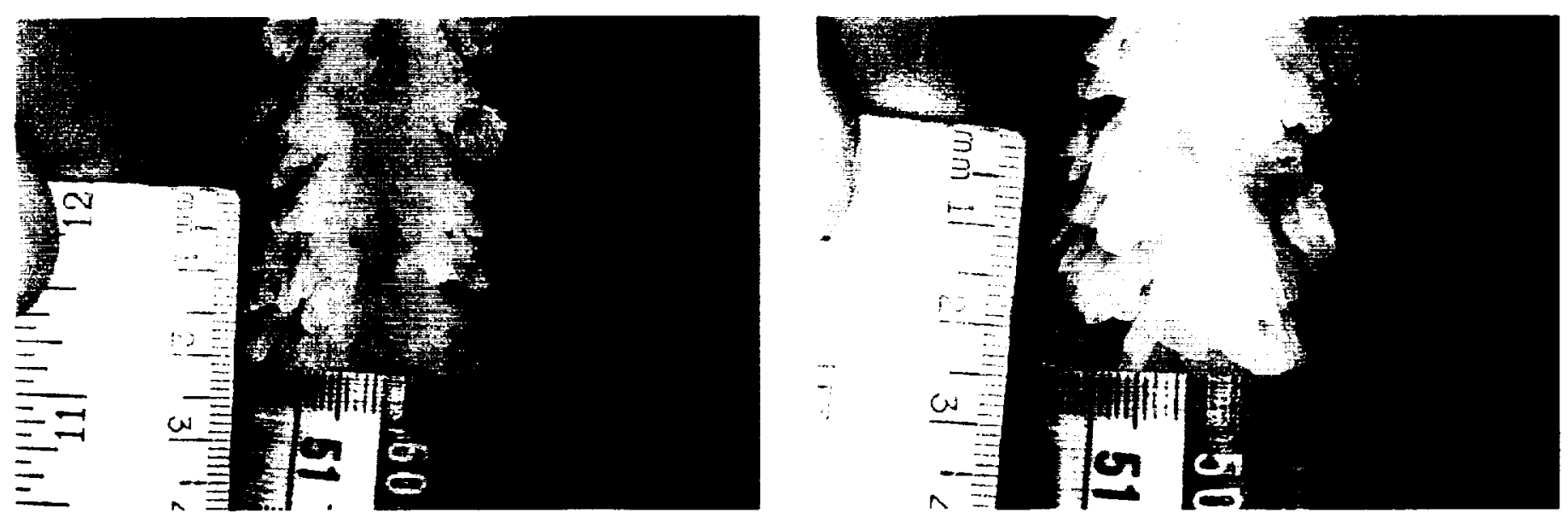

Figure 44. Front view of ice accretion at $\Lambda=35^{\circ}, V=150 \mathrm{mph}, T=20^{\circ} \mathrm{F} . \angle W C=0.75 \mathrm{~g} / \mathrm{m}^{3}$, $M V D=20 \mu \mathrm{m}, \tau=5 \mathrm{~min}$. Direction of flow is from bottom to top, scale of ruler is in centimeters. smallest division 1 millimeter.

Figure 45. Front view of ice accretion at $\Lambda=45^{\circ}, V=150 \mathrm{mph}, T=20^{\circ} \mathrm{F}, L W C=0.75 \mathrm{~g} / \mathrm{m}^{3}$ $M V D=20 \mu \mathrm{m}, \tau=5 \mathrm{~min}$. Direction of flow is from bottom to top. scale of ruler is in centimeters smallest division 1 millimeter. 


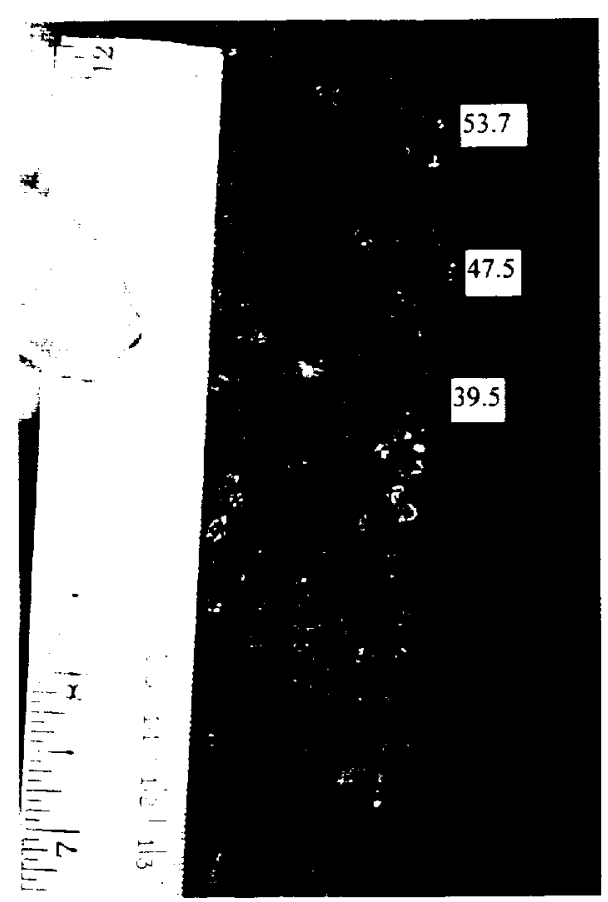

Figure 46. Side view of ice accretion on the end cap $\Lambda=0^{\circ}, V=150 \mathrm{mph}, T=30^{\circ} \mathrm{F}$, $L W C=0.75 \mathrm{~g} / \mathrm{m}^{3}$, MVD $=20 \mu \mathrm{m}, \quad \tau=5 \mathrm{~min}$. Direction of flow is from left to right, scale of ruler is in centimeters, smallest division 1 millimeter. The numbers on the airfoil indicate the local sweep angle.

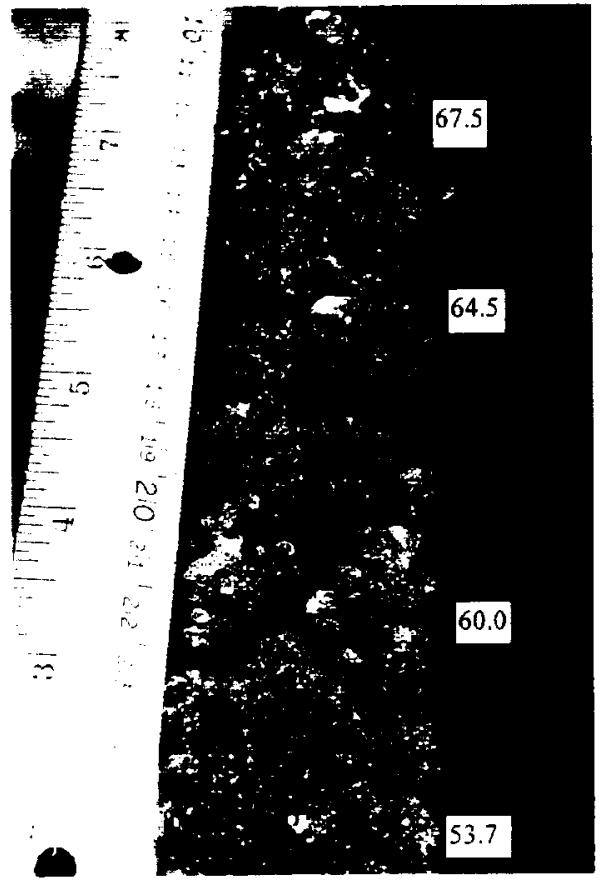

Figure 48. View of ice accretion on the end cap. $\quad \Lambda=0^{\circ}, \quad V=150 \mathrm{mph}, \quad T=30^{\circ} \mathrm{F}$, $L W C=0.75 \mathrm{~g} / \mathrm{m}^{3}, \quad M V D=20 \mu \mathrm{m}, \quad \tau=5 \mathrm{~min}$. Direction of flow is from bottom to top, scale of ruler is in centimeters, smallest division 1 millimeter. The numbers on the airfoil indicate the local sweep angle.
Figure 47. Front view of ice accretion at the beginning of the end cap. $\lambda=0^{\circ}, V=150 \mathrm{mph}$, $T=30^{\circ} \mathrm{F}, L W C=0.75 \mathrm{~g} / \mathrm{m}^{3}, M V D=20 \mu \mathrm{m}, \tau=5 \mathrm{~min}$. Direction of flow is from bottom to top, scale of ruler is in centimeters, smallest division 1 millimeter. The numbers on the airfoil indicate the local sweep angle

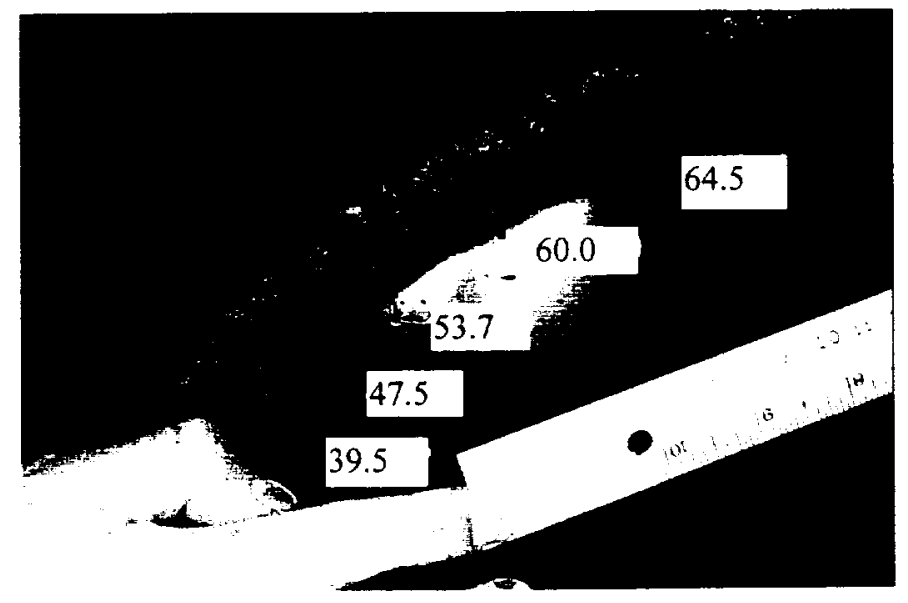

Figure 49. Side view of ice accretion on the end cap. $\Lambda=0^{\circ}, V=150 \mathrm{mph}, T=30^{\circ} \mathrm{F}$, $\mathrm{LWC}=0.75 \mathrm{~g} / \mathrm{m}^{3}, \quad M V D=20 \mu \mathrm{m}, \quad \tau=5 \mathrm{~min}$. Direction of flow is from left to right, scale of ruler is in centimeters, smallest division 1 millimeter. The numbers on the airfoil indicate the local sweep angle. 

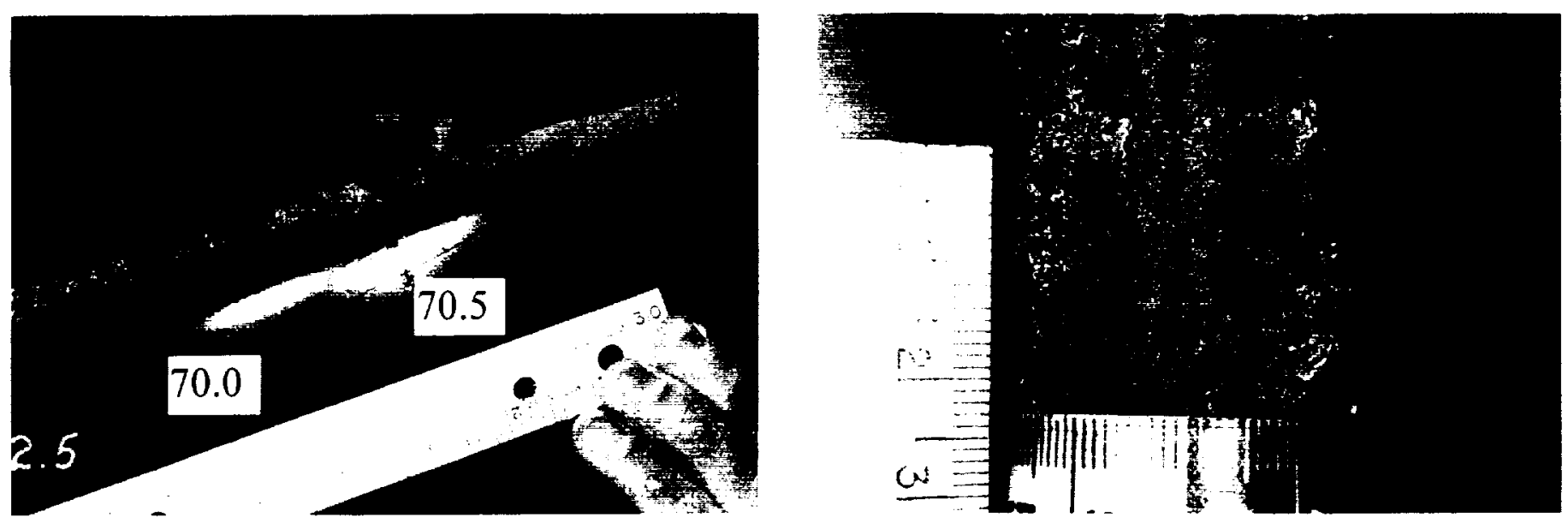

Figure 50. Side view of ice accretion at the end tip of the end cap. $\Lambda=0^{\circ}, V=150 \mathrm{mph}$, $\mathrm{T}=30^{\circ} \mathrm{F}, \mathrm{LWC}=0.75 \mathrm{~g} / \mathrm{m}^{3}, M V D=20 \mu \mathrm{m}, \tau=5 \mathrm{~min}$. Direction of flow is from left to right, scale of ruler is in centimeters, smallest division 1 millimeter. The numbers on the airfoil indicate the local sweep angle.

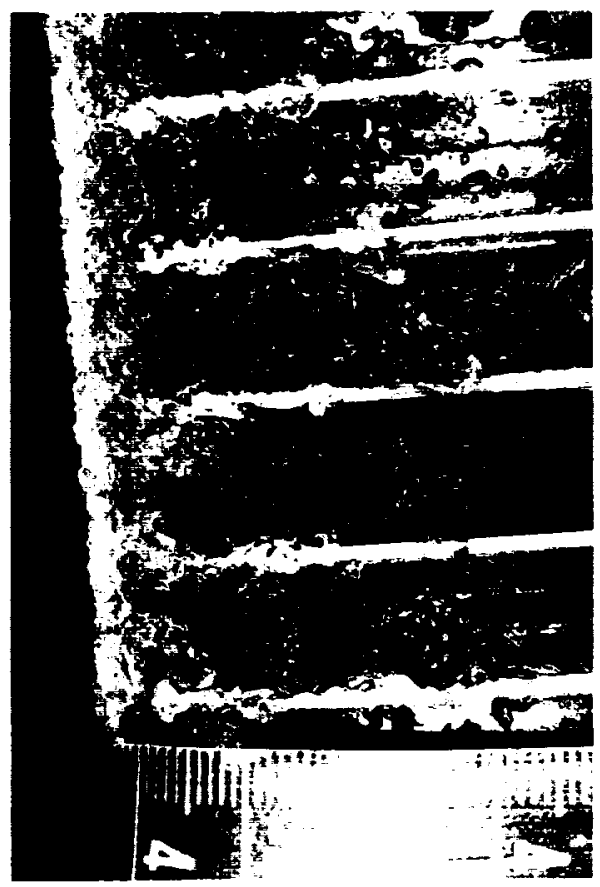

Figure 52. Side view of ice accretion at $\Lambda=0^{\circ}$ $V=150 \quad \mathrm{mph}, \quad T=30^{\circ} \mathrm{F}, \quad L W C=0.75 \mathrm{~g} / \mathrm{m}^{3}$ $M V D=20 \mu \mathrm{m}, \tau=5 \mathrm{~min}$. Direction of flow is from bottom to top. scale of ruler is in centimeters. smallest division 1 millimeter.

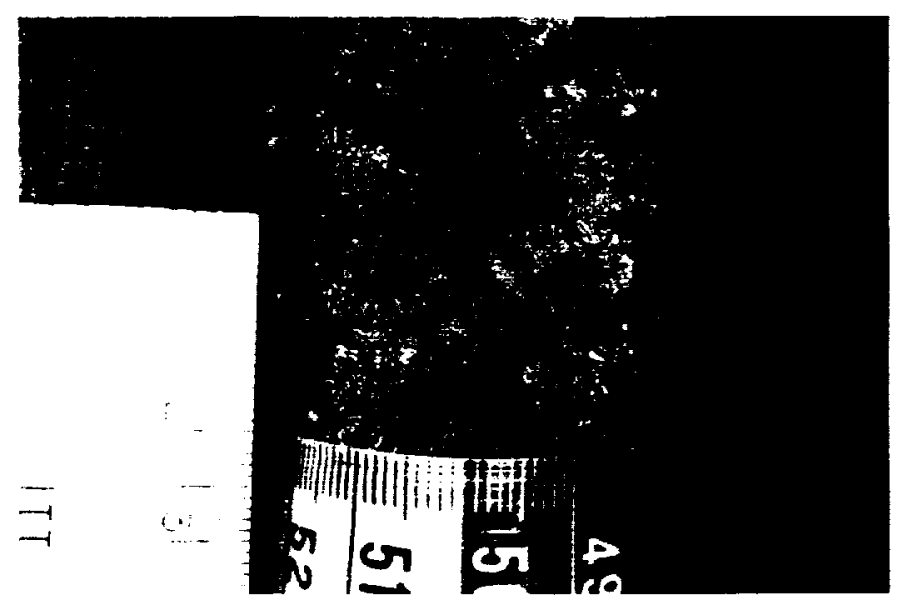

Figure 51. Front view of ice accretion at $\Lambda=0^{\circ}$. $V=150 \quad \mathrm{mph}, \quad T=30^{\circ} \mathrm{F}, \quad L W C=0.75 \mathrm{~g} / \mathrm{m}^{3}$. $M V D=20 \mu \mathrm{m}, \tau=5 \mathrm{~min}$. Direction of flow is from bottom to top, scale of ruler is in centimeters. smallest division 1 millimeter.

Figure 53. Front view of ice accretion at $\Lambda=25^{\circ}, V=150 \mathrm{mph}, T=30^{\circ} \mathrm{F}, L W C=0.75 \mathrm{~g} / \mathrm{m}^{3}$ $M V D=20 \mu \mathrm{m}, \tau=5 \mathrm{~min}$. Direction of flow is from bottom to top. scale of ruler is in centimeters. smallest division 1 millimeter 


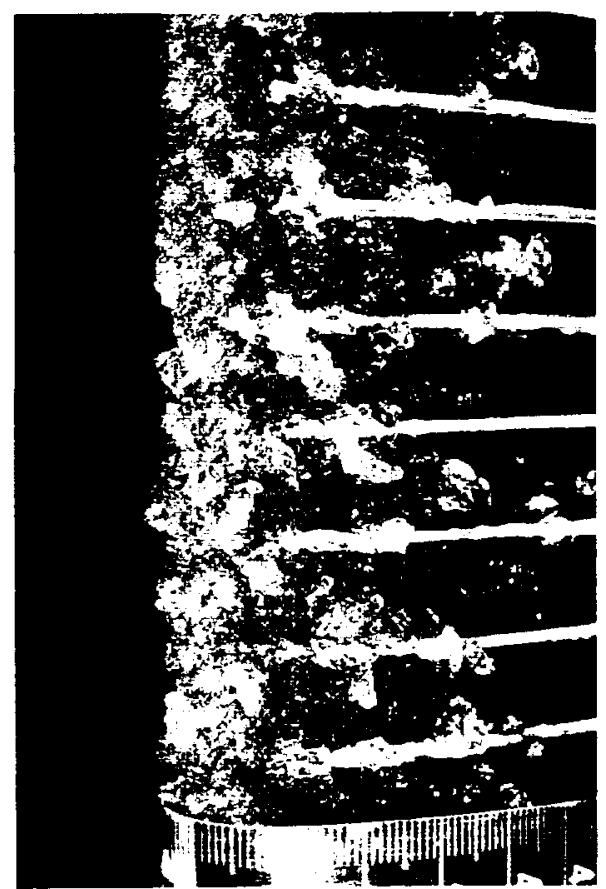

Figure 54. Side view of ice accretion at $\mathrm{A}=25^{\circ}$. $V=150 \quad \mathrm{mph}, \quad T=30^{\circ} \mathrm{F}, \quad L W C=0.75 \mathrm{~g} / \mathrm{m}^{3}$, $M V D=20 \mu \mathrm{m}, \tau=5 \mathrm{~min}$. Direction of flow is from bottom to top, scale of ruler is in centimeters. smallest division 1 millimeter

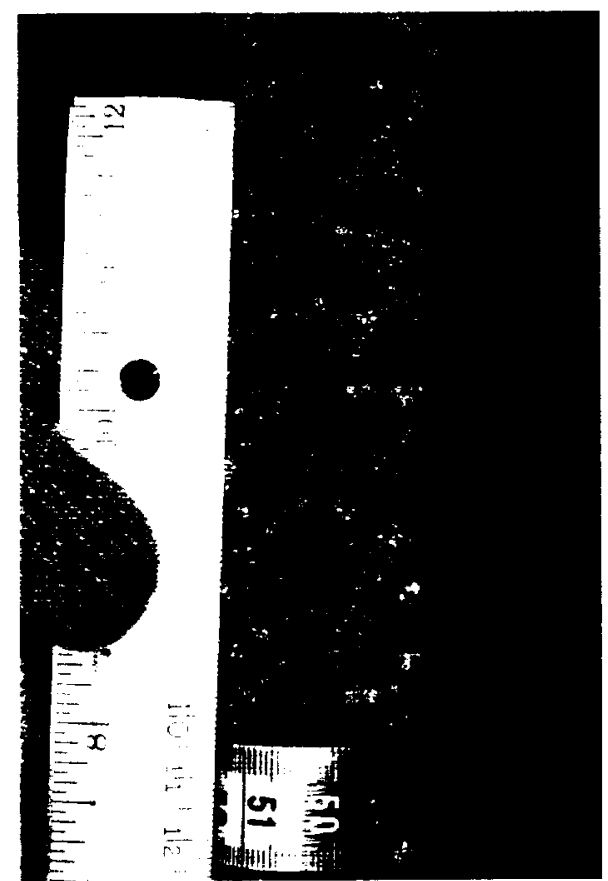

Figure 56. Front view of ice accretion at $\Lambda=45^{\circ}, V=150 \mathrm{mph}, T=30^{\circ} \mathrm{F}, L W C=0.75 \mathrm{~g} / \mathrm{m}^{3}$ $M V D=20 \mu \mathrm{m}, \tau=5 \mathrm{~min}$. Direction of flow is from bottom to top, scale of ruler is in centimeters, smallest division 1 millimeter

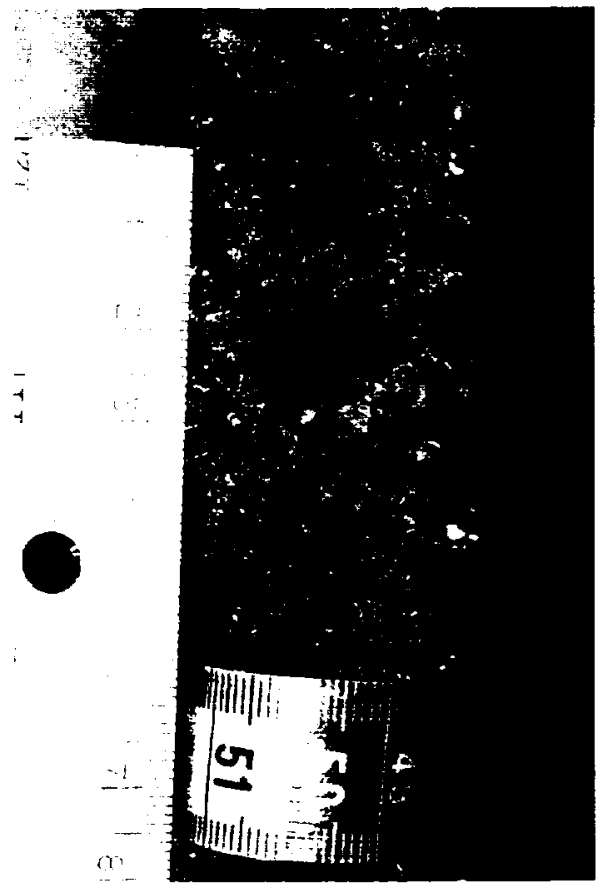

Figure 55. Front view of ice accretion at $\Lambda=40^{\circ}, V=150 \mathrm{mph}, T=30^{\circ} \mathrm{F}, L W C=0.75 \mathrm{~g} / \mathrm{m}^{3}$, $M V D=20 \mu \mathrm{m}, r=5 \mathrm{~min}$. Direction of flow is from bottom to top. scale of ruler is in centimeters, smallest division 1 millimeter 
Public reporting burden for this collection of information is estimated to average 1 hour per response, including the time for reviewing instructions, searching existing data sources, gathering and maintaining the data needed, and completing and reviewing the coliection of information. Send comments regarding this burden estimate or any other aspect of this collection of information, including suggestions for reducing this burden, to Washington Headquarlers Services, Directorate for Intormation Operations and Reports. 1215 Jefferson Davis Highway, Suite 1204, Arlingion, VA 22202-4302, and to the Office of Management and Budget, Paperwork Reduction Project (0704-0188), Washington, DC 20503.

1. AGENCY USE ONLY (Leave blank) 2. REPORT DATE 3. REPORT TYPE AND DATES COVERED

\section{TITLE AND SUBTITLE}

January $2(0) 0$

Technical Memorandum

LWC and Temperature Effects on Ice Accretion Formation on Swept Wings at Glaze Ice Conditions

\section{AUTHOR(S)}

Mario Vargas and Eli Reshotko

\section{PERFORMING ORGANIZATION NAME(S) AND ADDRESS(ES)}

National Aeronautics and Space Administration John H. Glenn Research Center at Lewis Field Cleveland, Ohio 44135-3191
5. FUNDING NUMBERS

WU-548-20-23-00

8. PERFORMING ORGANIZATION REPORT NUMBER

$E-12059$

\section{SPONSORING/MONITORING AGENCY NAME(S) AND ADDRESS(ES)}

National Aeronautics and Space Administration

Washington, DC 20546-0001
10. SPONSORING/MONITORING AGENCY REPORT NUMBER

NASA TM-2000-209777

AIAA-2(0)0-0483

\section{SUPPLEMENTARY NOTES}

Prepared for the 38th Aerospace Sciences Meeting and Exhibit sponsored by the American Institute of Aeronautics and Astronautics, Reno, Nevada. January 10-13, 2000. Mario Vargas, NASA Glenn Research Center; and Eli Reshotko, Case Western Reserve University, Department of Mechanical and Aerospace Engineering, Cleveland, Ohio 44106. Responsible person, Mario Vargas, organization code 5840, (216) 433-3943.

12a. DISTRIBUTION/AVAILABILITY STATEMENT 12b. DISTRIBUTION CODE

Unclassified - Unlimited

Subject Categories: 01 and 34

Distribution: Nonstandard

This publication is available from the NASA Center for AeroSpace Information, (301) 621-0390.

\section{ABSTRACT (Maximum 200 words)}

An experiment was conducted to study the effect of liquid water content and temperature on the critical distance in ice accretion formation on swept wings at glaze ice conditions. The critical distance is defined as the distance from the attachment line to the beginning of the zone where roughness elements develop into glaze ice feathers. A baseline case of $150 \mathrm{mph}, 25^{\circ} \mathrm{F}, 0.75 \mathrm{~g} / \mathrm{m}^{3}$ LWC and $20 \mu \mathrm{m}$ MVD was chosen. Icing runs were performed on a NACA 0012 swept wing tip at $150 \mathrm{mph}$ and MVD of $20 \mu \mathrm{m}$ for liquid water contents of $0.5 \mathrm{~g} / \mathrm{m}^{3}, 0.75 \mathrm{~g} / \mathrm{m}^{3}$, and $1.0 \mathrm{~g} / \mathrm{m}^{3}$, and for total temperatures of $20^{\circ} \mathrm{F}, 25^{\circ} \mathrm{F}$ and $30^{\circ} \mathrm{F}$. At each tunnel condition, the sweep angle was changed from $0^{\circ}$ to $45^{\circ}$ in $5^{\circ}$ increments. Casting data, ice shape tracings, and close-up photographic data were obtained. The results showed that decreasing the LWC to $0.5 \mathrm{~g} / \mathrm{m}^{3}$ decreases the value of the critical distance at a given sweep angle compared to the baseline case, and starts the formation of complete scallops at $30^{\circ}$ sweep angle. Increasing the LWC to $1.0 \mathrm{~g} / \mathrm{m}^{3}$ increases the value of the critical distance compared to the baseline case, the critical distance remains always above 0 millimeters and complete scallops are not formed. Decreasing the total temperature to $20^{\circ} \mathrm{F}$ decreases the critical distance with respect to the baseline case and formation of complete scallops begins at $25^{\circ}$ sweep angle. When the total temperature is increased to $30^{\circ} \mathrm{F}$, bumps covered with roughness elements appear on the ice accretion at $25^{\circ}$ and $30^{\circ}$ sweep angles, large ice structures appear at $35^{\circ}$ and $40^{\circ}$ sweep angles, and complete scallops are formed at $45^{\circ}$ sweep angle.

\section{SUBJECT TERMS}

Ice formation; Swept wings; Cross flow instability

15. NUMBER OF PAGES 35

16. PRICE CODE

$$
\mathrm{A} 03
$$

\begin{tabular}{|c|c|}
\hline $\begin{array}{c}\text { 17. SECURITY CLASSIFICATION } \\
\text { OF REPORT } \\
\text { Unclassified }\end{array}$ & $\begin{array}{c}\text { 18. SECURITY CLASSIFICATION } \\
\text { OF THIS PAGE } \\
\text { Unclassified }\end{array}$ \\
\hline
\end{tabular}
19. SECURITY CLASSIFICATION
OF ABSTRACT Unclassified 
